\title{
The Absent Made Present: Portraying Nuns in the Early Modern Low Countries
}

\author{
Margit Thøfner
}

Over the recent decades scholarly work on early modern nuns has truly taken off, a happy consequence of the general growth of interest in gender history. Nuns have been studied in terms of their social and political lives, their devotional and musical practices, their artistic and architectural patronage and much else besides. ${ }^{1}$ There is nevertheless something of a lacuna in this burgeoning field: portraiture. ${ }^{2}$ To my knowledge there are only two authors who have engaged directly with the portrayal of early modern nuns, James Córdova and Mónica Díaz, and they focus exclusively on New Spain and New France. ${ }^{3}$ Of course, there are also useful broader surveys of conventual visual culture such as Paul Vandenbroeck's justifiably famous and methodologically provocative exhibition catalogue of 1994, Hooglied/Le Jardin clos d'âme. ${ }^{4}$ This

1 This body of literature is far too large to enumerate here but good examples include: Silvia Evangelisti, Nuns: A History of Convent Life, 1450-1700 (Oxford and New York: Oxford University Press, 2007); Robert L. Kendrick, Celestial Sirens: Nuns and their Music in Early Modern Milan (Oxford: Clarendon, 1996); Benjamin Paul, Nuns and Reform Art in Early Modern Venice: The Architecture of Santi Cosma e Damiano and its Decoration from Tintoretto to Tiepolo (Farnham: Ashgate, 2012); Cordula van Wyhe, ed., Female Monasticism in Early Modern Europe: An Interdisciplinary View (Aldershot: Ashgate, 2008); Claire Walker, Gender and Politics in Early Modern Europe: English Convents in France and the Low Countries, (Basingstoke: Palgrave, 2003); Charlotte Woodford, Nuns as Historians in Early Modern Germany (Oxford and New York: Oxford University Press, 2002).

2 For example, it is a striking absence in this otherwise excellent volume: Andrea Pearson, ed., Women and Portraits in Early Modern Europe (Aldershot: Ashgate, 2008).

3 James M. Córdova, "Clad in Flowers: Indigenous Arts and Knowledge in Colonial Mexican Convents," Art Bulletin 93 (2011): 449-467; James M. Córdova, The Art of Professing in Bourbon Mexico: Crowned-Nun Portraits and Reform in the Convent (Austin: University of Texas Press, 2014), 148-172; Mónica Díaz, "Native American Women and Religion in the American Colonies: Textual and Visual Traces of an Imagined Community," Legacy 28 (2011): 205-231. Although focused on a triptych and a diptych from the early sixteenth century, useful points are also made in Andrea G. Pearson, "Nuns, Images, and the Ideals of Women's Monasticism: Two Paintings from the Cistercian Convent of Flines," Renaissance Quarterly 54 (2001): 1356-1402.

4 Paul Vandenbroeck, ed, Hooglied. De beeldwereld van religieuze vrouwen in de Zuidelijke Nederlanden vanaf de 1зе eeuw (Brussels and Ghent; Paleis voor Schone Kunsten, 1994); 
catalogue helpfully includes a number of southern Netherlandish portraits of nuns although they are not discussed in any detail in the text. In addition, historians like Silvia Evangelisti and Sarah Moran have made thoughtful comments on the portrayal of religious women within broader discussions of life and visual culture in convents and beguinages. ${ }^{5}$ But, to date, there has been no dedicated study focusing sharply in on this particular body of early modern pictorial practices.

Accordingly, this essay is a first exploration of the problems and issues that come into play when considering portraits of early modern nuns. Due to its preliminary nature, the discussion is divided into four sections, a pair on faces and then a pair on places. The first of these four sections is an attempt to define the area of study and also to explore its limits. The second examines the making of nuns' portraits whilst the third and fourth explore two of their distinct historical functions, one familial, the other conventual. It should be underscored that, as a whole, the present essay is neither comprehensive nor exhaustive, merely an attempt to stimulate further interest in an important and challenging body of historical and art-historical evidence. \\ Faces (I): Definitions, Limits and Pictorial Problems}

First there is the question of what constitutes an early modern nun. It is easiest to focus on those who inhabited the strict enclosure generally enforced after the Council of Trent and this, indeed, is what most of the present essay does but purely for reasons of length and manageability. It must be stressed that, especially in the Netherlands, there were many less formalised groups of devout women, including spiritual daughters, beguines and klopjes, who lived religious lives without taking formal vows and thus were not subject to claustration. Equally, there were hospital sisters whose caring for the sick meant that enclosure could only ever be partial. Moreover, in the seventeenth

Paul Vandenbroeck, ed, Le Jardin clos de l'âme (Brussels and Ghent: Palais des Beaux-Arts de Bruxelles, 1994). All subsequent references are to the Dutch version.

5 Evangelisti, Nuns, 170-174; Sarah J. Moran, "Women at Work: Governance and Financial Administration at the Court Beguinages of the Southern Low Countries in the Seventeenth and Eighteenth Centuries," Journal of Early Modern History 22 (2018): forthcoming and Sarah J. Moran, Visual Culture at the Court Beguinages of the Habsburg Low Countries: Unconventual Women 1585-1794, Amsterdam University Press, forthcoming. I am very grateful to Sarah Moran for permitting me access to her important article and the equally insightful relevant chapter of her book in their unpublished form. 
century there came the new female teaching orders, for example the Ursulines, who quickly learned to work both with and against claustration. ${ }^{6}$

Second, there are problems of geography. On the basis of exhaustive work on profession and other conventual portraits from New Spain, Córdova has argued that the specific forms taken by these images are a relatively local phenomenon, pertaining to certain Hispanic colonies (for an example of such a profession portrait, see Fig. 4.1). ${ }^{7}$ Whether this is really so requires further exploration but Córdova nevertheless raises an important point: one should be careful about how to delimit the study of early modern nuns' portraits. Presentday geographical, political or linguistic boundaries will not suffice. This is particularly the case for the early modern Netherlands, which were tightly bound into the Hispano-Portuguese Empire, whether as subjects or sworn enemies. ${ }^{8}$

In fact, in the early modern world, portraits of nuns and female novices were simultaneously a local and an international phenomenon - a type of imagery produced all over the Roman Catholic world, ranging from the Netherlands, France, Spain and Italy through to the so-called New World (for examples, see Figs. 4.1-4.7). That, in turn, is because of the para-national nature of much of early modern monasticism. A community of, say, Benedictine or Augustinian or Carmelite nuns were most certainly defined by their specific location but also by their province and their allegiance to the Superiors of their respective Orders, usually resident in Rome. And there was normally a lively correspondence between the three and sometimes nuns and their superiors would travel long distances, for example to found new communities or to support established ones that had run into trouble. ${ }^{9}$ Less strictly defined sisters in religion,

6 A good overview of the various types of female orders to be found in the early modern Netherlands may be gained from Craig Harline, "Actives and Contemplatives: The Female Religious of the Low Countries before and after Trent," The Catholic Historical Review 81 (1995): 541-567. On the spiritual daughters, individual lay women under Jesuit direction, see Ellen A. Macek, "Ghostly Fathers and Their Virtuous Daughters: The Role of Spiritual Direction in the Lives of Three Early Modern English Women," The Catholic Historical Review 90 (2004): 213-235; on beguines, see Moran, "Women at Work"; on klopjes, see Joke Spaans, De Levens der Maechden: Het Verhaal van een Religieuze Vrouwengemeenschap in de eerste helft van de zeventiende eeuw (Hilversum: Verloren, 2012).

7 Córdova, "Clad in Flowers," 449-467; Córdova, The Art of Professing in Bourbon Mexico, 148-172.

8 This, of course, follows the thesis expounded by Jonathan I. Israel, The Dutch Republic and the Hispanic World, 1606-1661 (Oxford: Clarendon, 1982).

9 Consider, for example, the journeys made by Ana de Jesus, a close friend of St Teresa of Avila and foundress of Discalced Carmelite convents in Spain, France and the Low Countries. [Anna of Jesus of Notre Dame de Namur], Life of the Venerable Anne of Jesus, Companion of St. Teresa of Avila (London: Sands, [1932]), 6o-71, 94, 130-131, 168-229. See also I. Rosier, 


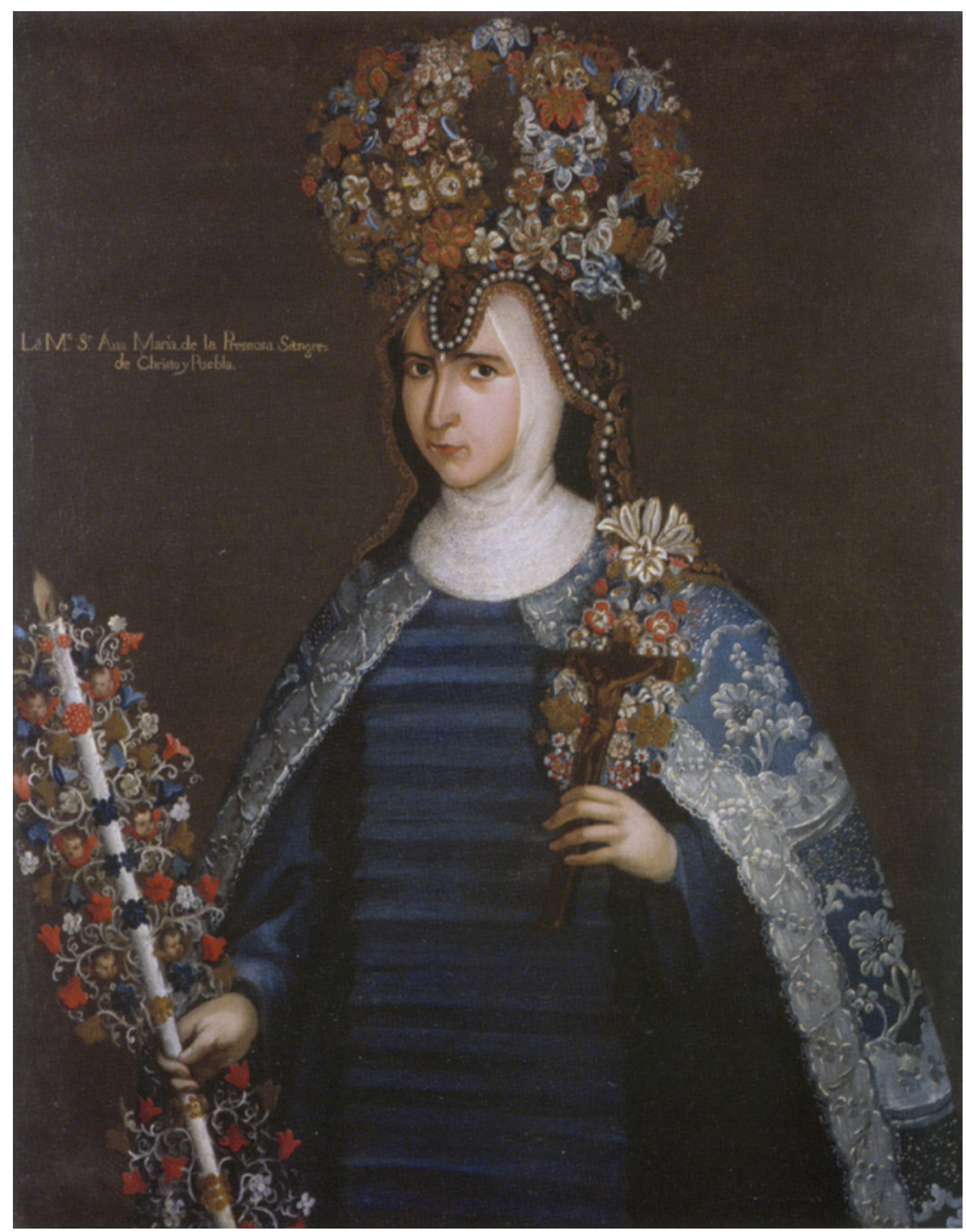

FIgURE 4.1 Anonymous, Ana Maria de la Preciosa Sangre de Cristo, c. 1770. Denver Art Museum, Denver 


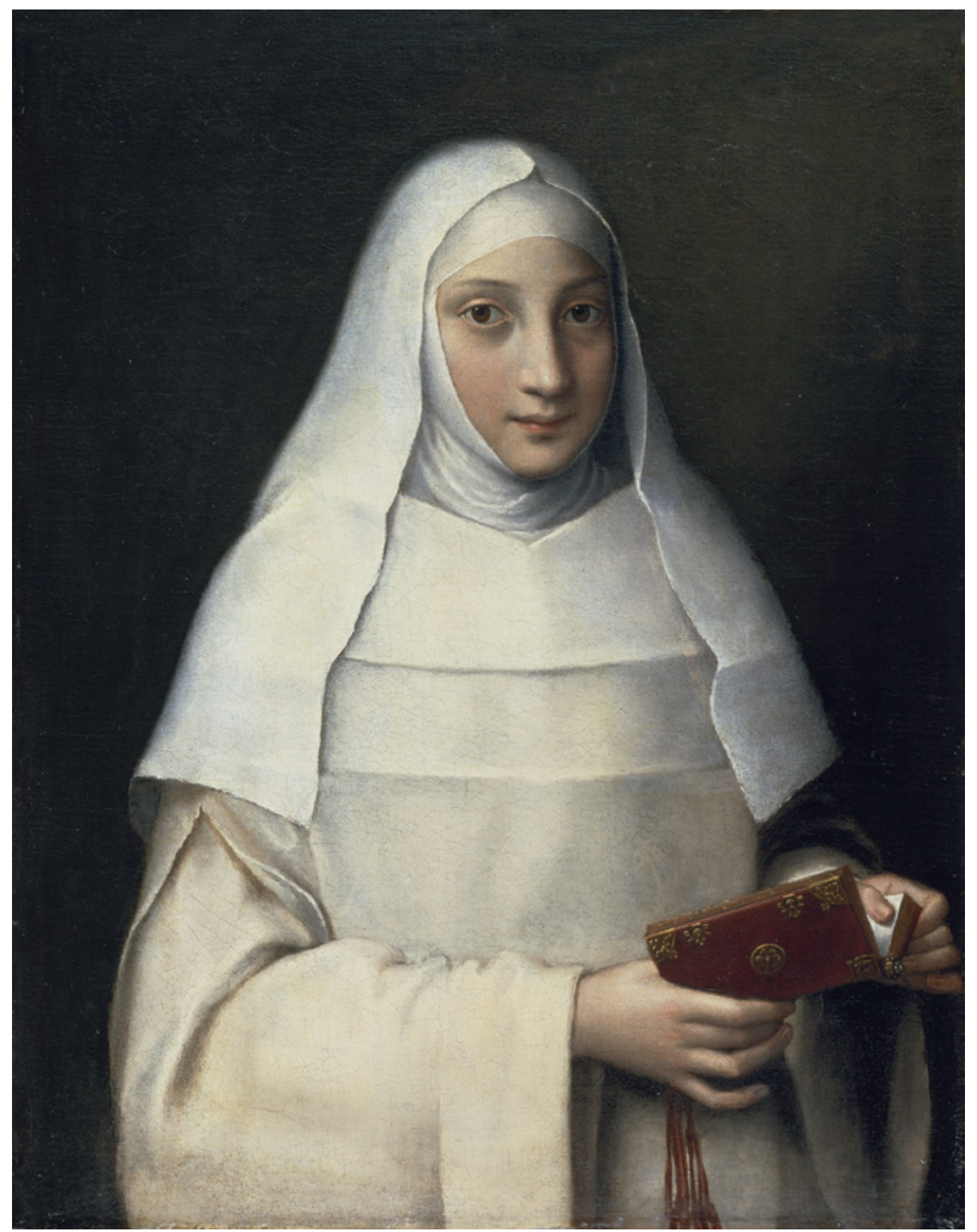

FIGURE 4.2 Sofonisba Anguissola, Elena Anguissola, 1551, City Art Gallery, Southampton 


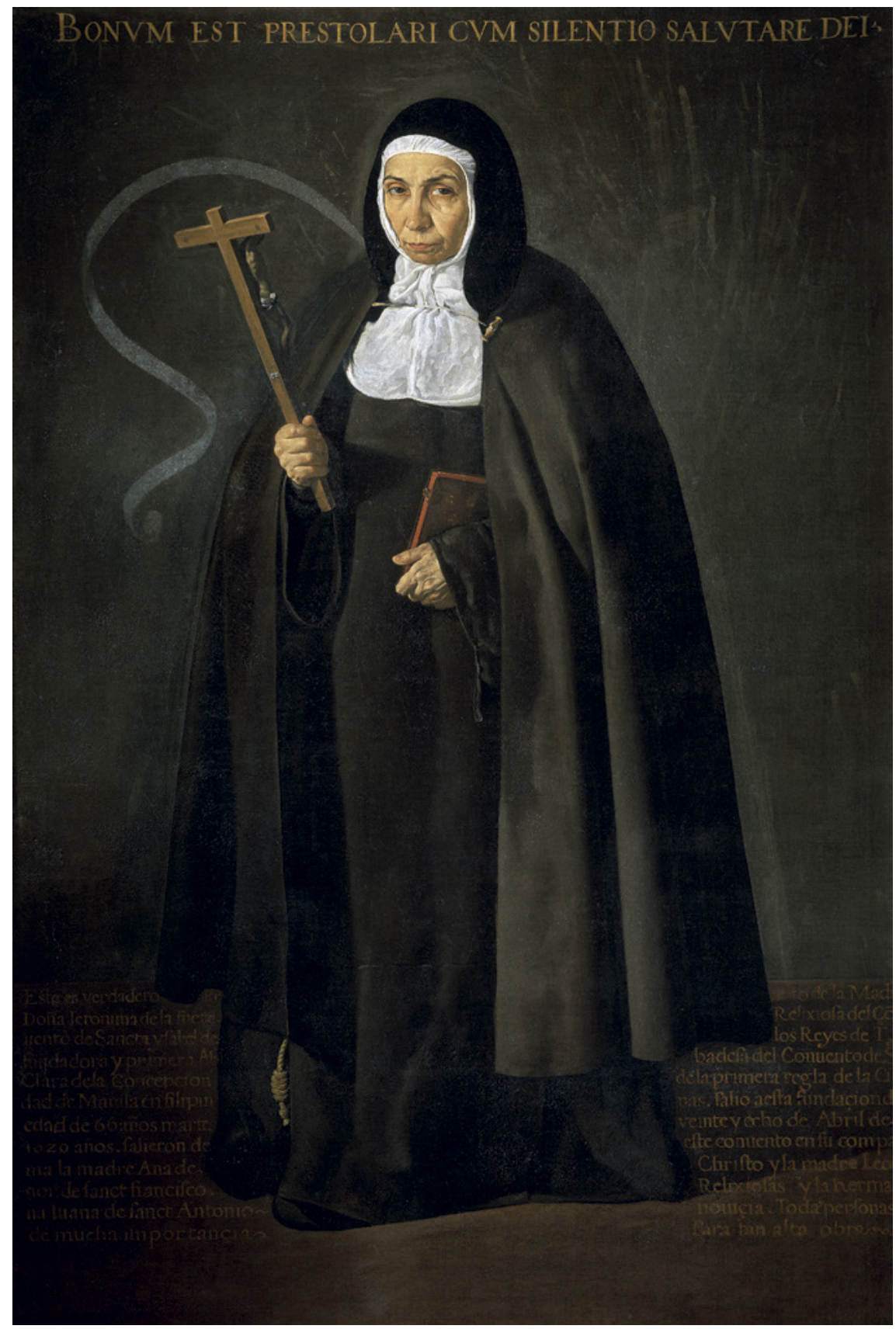

FIGURE 4.3 Diego Velazquez, Jeronima de la Fuente, 1620, Museo Nacional del Prado, Madrid 


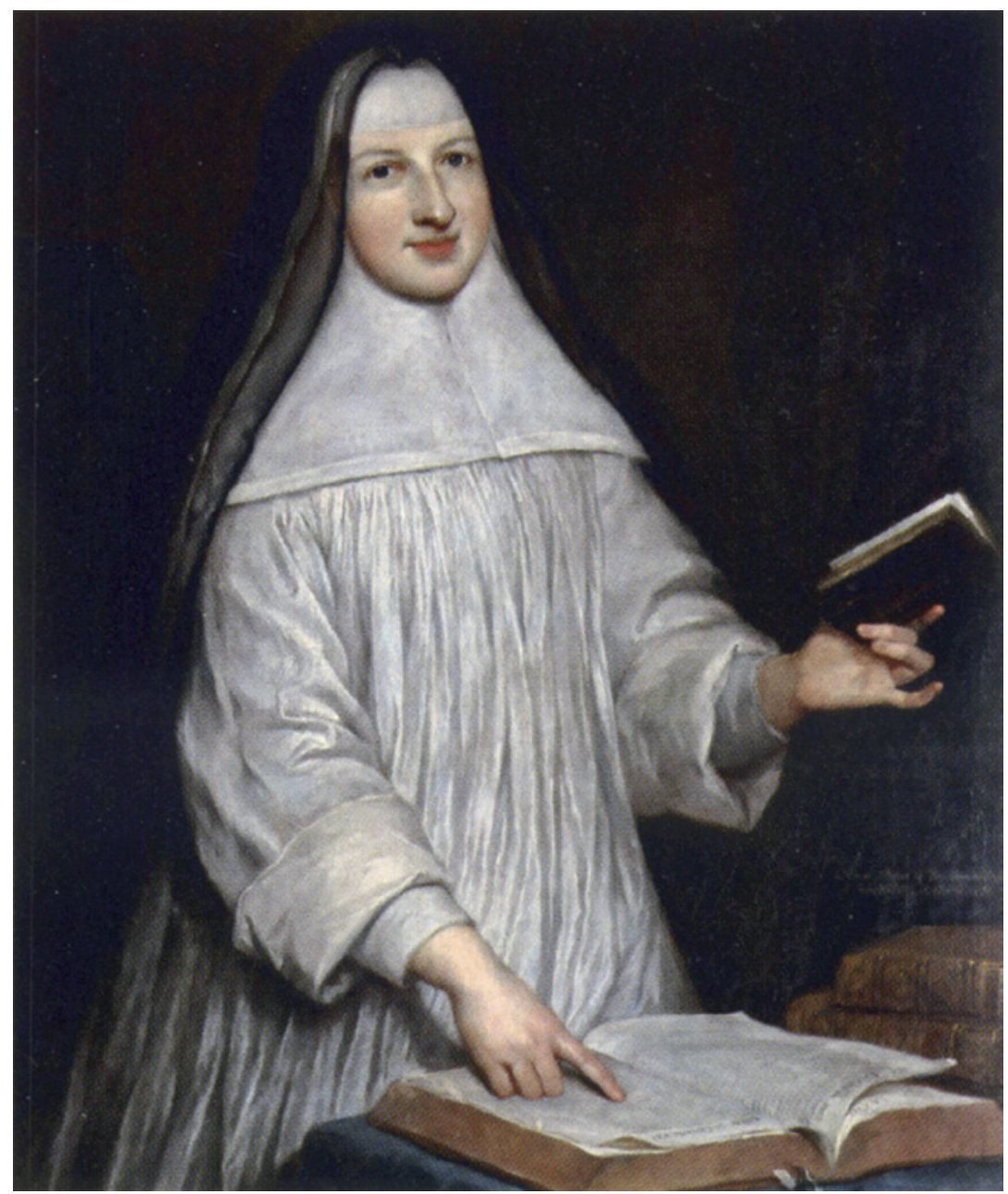

FIGURE 4.4 Attributed to Jean-Francois de Troy, Anne Stonor, c. 1725, Stonor Park, Oxfordshire

such as beguines, were even freer to travel. ${ }^{10}$ In short, early modern monasticism was a geographically fluid phenomenon and, in acknowledgement of that, what follows is not confined strictly to the Netherlands.

Biographisch en Bibliographisch overzicht van de vroomheid in de Nederlandse Carmel van 1235 tot het midden der achttiende eeuw (Tielt: Lannoo, 1950), 159-16o.

10 See, for example, the ease with which beguines from Antwerp travelled back and forth to visit the Premonstratensian nuns of Oosterhout: Trees Sponselee-de Meester, Het Norbertinessenklooster Sint-Catharinadal in de Staatse periode 1625-1795: portret van een religieuze vrouwengemeenschap in benarde tijden (Hilversum: Verloren, 2003), 171-173. See also Moran, Visual Culture at the Court Beguinages, forthcoming. 
Third, there is the issue of anonymity. Many surviving early modern portraits of nuns are difficult to anchor historically because either sitter or artist or both remain stubbornly unknowable. That, in turn, is often a stumbling block to serious art-historical investigation; as a discipline, we are not good at valuing and otherwise engaging with unnamed works. Consider, for example, the provenance of one portrait of a Carmelite novice, chosen more or less at random (Fig. 4.5). It seems that the existence of this painting was only registered publicly when it passed through the London art market in 2008, tentatively attributed to Philippe de Champaigne. Trained in Brussels, de Champaigne spent most of his working life in France where he did indeed produce elegantly understated portraits of nuns, perhaps in part because his only daughter Catherine was a Cistercian at Port-Royal in Paris. ${ }^{11}$ The attribution, however, was based more on wishful thinking than on proper engagement with the painting. In 2011 the portrait went through the art market again and, as an attentive conservator then noticed, it is actually signed by one Pieter Leermans and dated 1678 . Leermans is a rather obscure painter from Leiden, possibly a pupil of Gerard Dou. ${ }^{12}$ So at least this portrait now comes with a distinct Netherlandish context but it has not yet been possible to identify the sitter although the coat of arms may eventually yield something. It does not help that the portrait has yet again disappeared into private ownership.

Such intractably anonymous images regularly go through the art market where they fetch relatively low prices and then disappear into private collections. This is one symptom of the systematic erosion of monasticism in the Netherlands that began with Joseph II's dissolution of contemplative communities and which is still continuing under the twin pressures of secularisation and capitalism. ${ }^{13}$ From a historical point of view, it is unfortunate because it compromises our ability to study the role that portraiture played in early modern monastic culture.

Besides this, even when the portrait is associated with a well-known artist, for example somebody like Peter Paul Rubens, it can be difficult to identify the sitter. For many years there was doubt about the identity of the nun in the

11 On the relationship between de Champaigne and the nuns of Port Royal, see Olin D. Rand, "Philippe de Champaigne and the Ex-Voto of 1662: A Historical Perspective," Art Bulletin 65 (1983): 78-92.

12 Hans Volmer, ed., Allgemeines Lexicon der Bildenden Künstler von der Antike bis zur Gegenwart (begründet von Ulrich Thieme und Felix Becker) (Leipzig: Seeman, 1928), vol. 22, 546. The fact that Leermans can only be found in Thieme-Becker evinces his obscurity.

13 Harline, "Actives and Contemplatives," $55^{8}$ and 564 . Further insights may be gained from Urs Altermatt, Jan de Mayer and Franziska Metzger, eds., Religious Institutes and Catholic Culture in Nineteenth- and Twentieth-Century Europe (Leiden: Leiden University Press, 2014). 


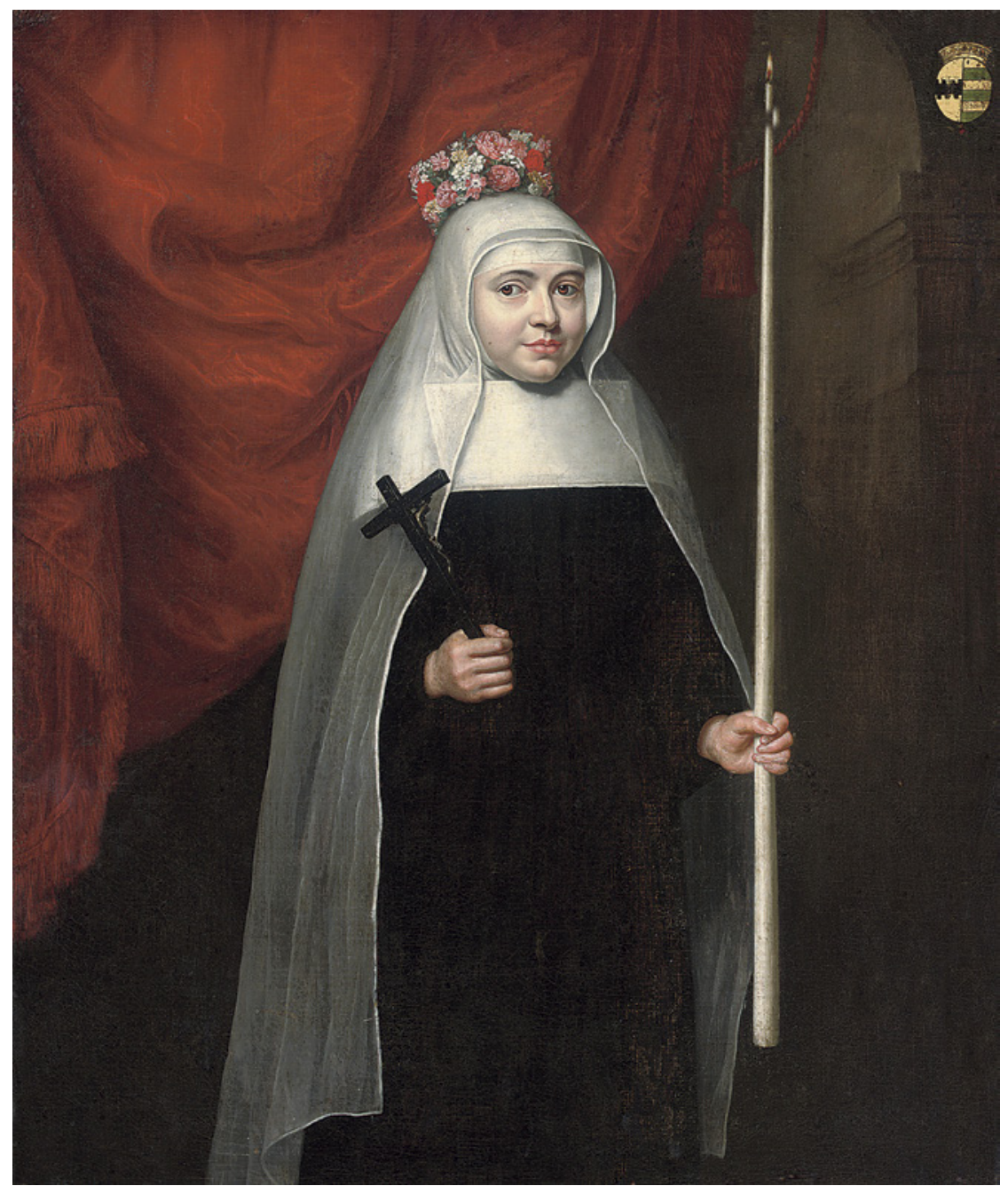

FIGURE 4.5 Pieter Leermans, Portrait of a Carmelite Novice, 1678, present whereabouts unknown

portrait at Apsley House (Fig. 4.6). It was only when a sharp-eyed art historian noted an explicitly named copy in the Descalzas Reales in Madrid that the sitter was finally named as Ana Dorotea of Habsburg, the illegitimate daughter of the Holy Roman Emperor Rudolph II. $^{14}$ So, as demonstrated by the three examples discussed so far, getting scholarly purchase on nuns' portraits is not

14 Frances Huemer, Portraits I - Corpus Rubenianum Ludwig Burchard, part XIX (Brussels: Arcade Press, 1977), 101-102. 


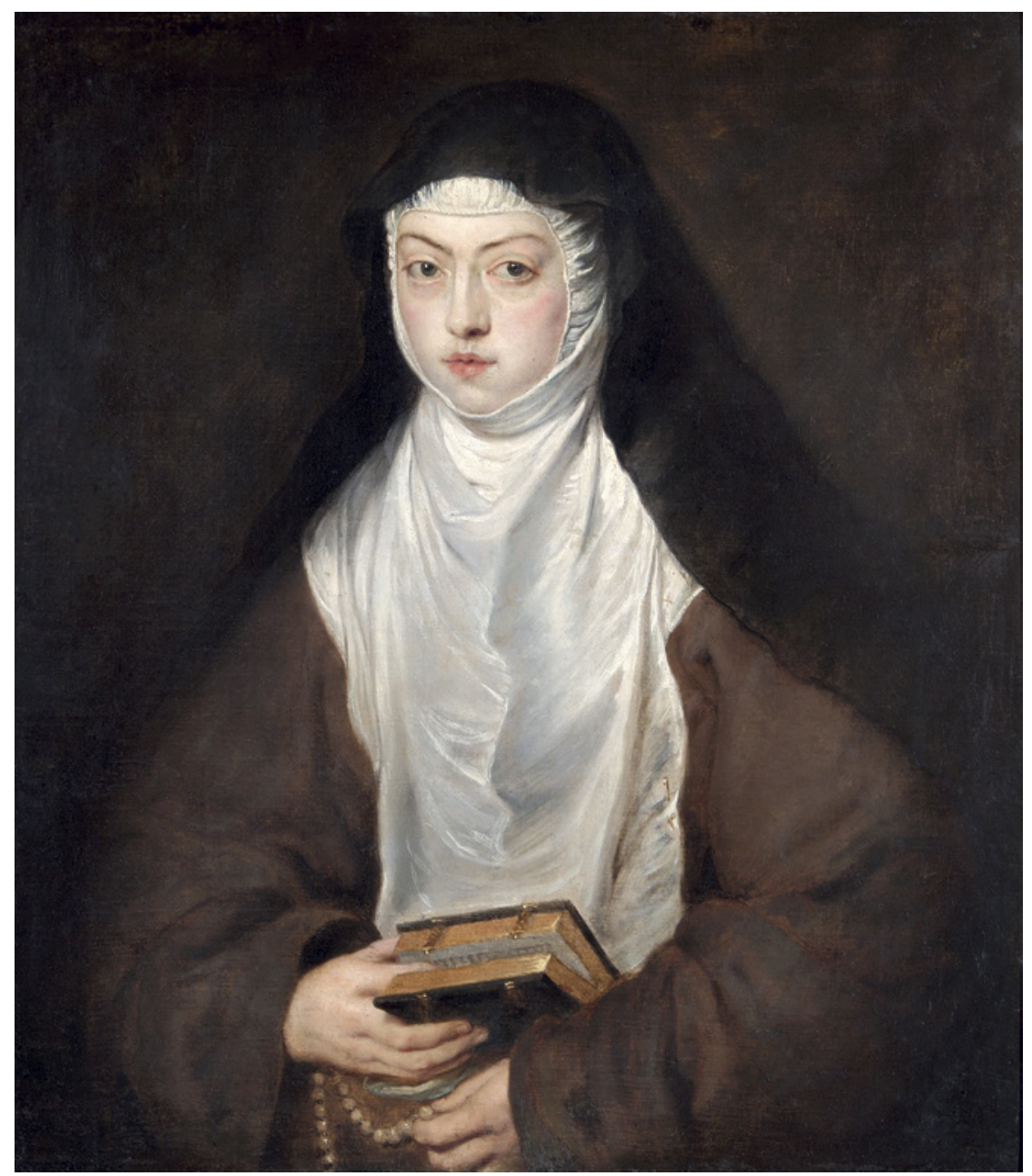

FIGURE 4.6 Peter Paul Rubens, Ana Dorotea of Habsburg, 1628, Apsley House, London

easy. Amongst other things, it involves careful visual analysis and a honed knowledge of cognate examples. It may be that the latter can only be fully acquired by constructing an extensive catalogue or database of such images but that is beyond the scope of this essay.

As all this suggests, studying early modern nuns' portraits can be frustrating. In essence, they are highly conventional. ${ }^{15}$ The format is usually bust or

15 Of course, there are conventional aspects to be found in most early modern European portraiture. See Joanna Woodall, "Introduction: facing the subject" in Portraiture: Facing the Subject, ed. Joanna Woodall (Manchester and New York: Manchester University Press, 
half-length, great attention is paid to the fall of the veil and the voluminous habit, the facial features are often quite generic, and one or both hands are demurely folded across the body or else hold some suitable devotional accoutrement. If there is additional detail it is usually devotional paraphernalia like skulls, books, crucifixes, rosaries or a combination of these. Frankly, the iconography is somewhat tedious and the overall quality frequently less than satisfactory. In short, nuns' portraits often come with limited contextual documentation and in visual terms there is also little to work with.

Even so, for a number of reasons it is important to engage with this type of portraiture. One has already been clearly articulated by Silvia Evangelisti, for whom portraits "confirmed the nuns' intermediate position between heaven and earth, though firmly asserting their roots in their family and the terrestrial community."16 Whilst she does not offer any detailed analysis of specific portraits to substantiate this point, it is at least a start. For, as Evangelisti suggests, without the study of nuns' portraits we miss a vital form of historical evidence pertaining to their lives, to their particular combination of religious and social roles. And there are also more specific art-historical reasons for studying nuns' portraits. These images constitute an overtly gendered sub-genre of portraiture - something that is already implied by their uniformity, their frustrating conventionality. They take us to the heart of what it meant to portray women in the early modern Netherlands.

The gendered qualities of nuns' portraits become obvious when compared with images of monks or friars. Consider, for example, the differences between Rubens's painting of Ana Dorotea and his portrait of the Dominican friar Michael Ophovius (Figs. 4.6 and 4.7). Ophovius, as is fitting for a provincial of the Order of Preachers, is shown with his mouth slightly open as if speaking directly to the viewer, whilst also addressing us with his gaze and hands. ${ }^{17}$ At the same time, the lower parts of his body are modestly sheltered by the drawing of his mantle across it, surely an allusion to clerical celibacy yet equally evocative of a cerebral as opposed to physical personality. Even so, on balance, Ophovius's portrait comes with a sense of bodily openness quite different from the self-enclosing pose that Rubens gave to Ana Dorotea. Her gaze also addresses the audience but her body, apart from her face and hands, is enfolded in her voluminous Franciscan habit. Furthermore, the view to

1997), 1-25, especially 2 . What seems to be distinct about nuns' portraits is their unusually high degree of conventionality.

16 Evangelisti, Nuns, 175.

17 Hans Vlieghe, Portraits II, Antwerp: Identified Sitters - Corpus Rubenianum Ludwig Burchard, part XIX (London: Harvey Miller, 1987), 139-142. 


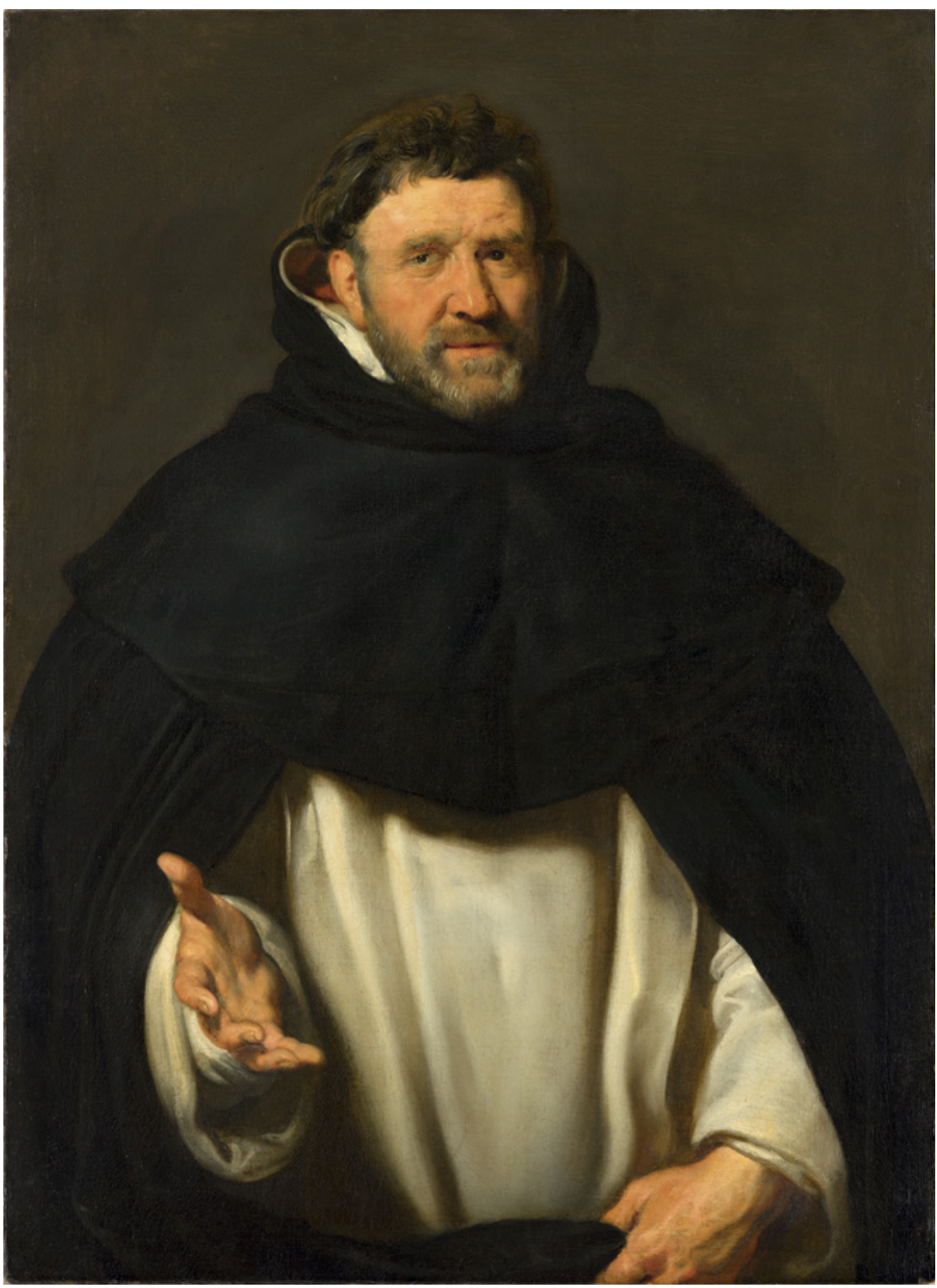

FIg URE 4.7 Peter Paul Rubens, Michiel Ophovius, c. 1615-17, Mauritshuis, The Hague

her stomach is virtually obscured by the book and rosary beads held in her drawn-in hands. Whilst Ophovius's hands address us, Ana Dorotea's turn in on herself in what seems a protective, even apotropaic gesture. For the nun, the allusion to chastity is much more overt; she is, quite literally, enclosing herself, simultaneously emphasising and withholding her physicality. Thus these two 
portraits come with quite distinct pictorial concerns. In them, Rubens - ever sensitive to the relationship between gender and pictorial decorum as well as to existing visual conventions - formulates two distinct pictorial personae. One is masculine and cerebral, appropriate for a Dominican academic, preacher and provincial, the other feminine and far more emphatically virginal, for a cloistered nun of the Imperial bloodline.

The most striking difference between the two is the covering of Ana Dorotea's head and hair, which in any case would have been shorn. Of course this was a standard monastic requirement for women. Nevertheless, it poses distinct problems for portrait painters. Unable to convey the texture and colour of hair, it compromises somewhat their ability to evoke individual presence, maybe one reason for our frequent inability to identify female monastic sitters. In Ana Dorotea's case, as in several of the examples discussed in this essay, that problem is exacerbated by the emphasis on her pale and youthful skin. It does not have the wrinkles, puckered brow and other distinguishing characteristics that Rubens worked across the friar's visage - although this is countered, to an extent, by the unusually large, slightly protuberant eyes. As a whole, Ana Dorotea's face is carefully balanced between a relatively recognisable likeness and a generic early modern ideal of youthful feminine beauty (a pictorial tension also observable in Figs. 4.2, 4.4, and 4.5 and, indeed, to be found in many early modern portraits of women). That is to say: portraying early modern nuns came with a set of gender-specific pictorial problems, distinct from those pertaining to painting male religious.

This both confirms and expands Evangelisti's point: nuns' portraits divulge a great deal about how gendered identities were articulated and perpetuated visually in the early modern period. Given this, they surely need to be studied in more detail despite their attendant problems. For they help to illuminate the contradictions and paradoxes inherent in the lives of early modern nuns, especially but not exclusively of the cloistered variety. More broadly, it is important to remember that, at least in the southern Netherlands, to be a cloistered nun or hospital sister or beguine was to take on a socially important yet distinctly gendered personal role; monastic life was a real alternative for women who did not wish to become wives or mothers. ${ }^{18}$ Because of this nuns' portraits are, quite simply, important facets of gender history.

One final caveat: this essay deliberately eschews various categories of conventual portraiture, including printed works, group portraits and portraits set

18 Harline, "Actives and Contemplatives," especially $565^{-5}{ }^{6} 7$. See also Tine de Moor, "Single, safe, and sorry? Explaining the early modern beguine movement in the Low Countries," Journal of Family History 39 (2014): 3-21. 
within broader narrative or devotional scenes. This is not to imply that such images are unimportant or unrelated to the topic in hand - they most certainly are, and deserve more and deeper study. But, for the sake of brevity, most of the present argument focuses on paintings where one single religious woman is portrayed as a distinct person - or rather as a persona - as an individual who embodies a particular social and religious ideal: that of the impeccably virtuous and chaste nun.

\section{$2 \quad$ Faces (II): Painting Portraits}

Now, to take early modern nuns' portraits seriously as historical evidence entails considering how and why they were made. The first point to be made here is that the making of a portrait usually involved some form of financial transaction. Most paintings of nuns were paid for either by the sitter herself or by somebody else desirous of owning her image; it is generally the case that female portraits of the early modern period were as likely to be paid for by relatives or admirers as by the sitter herself. ${ }^{19}$ This is clear, for example, from the account book kept by the German artist Albrecht Dürer while visiting the Low Countries. In Antwerp in November $15^{20}$ he drew a portrait (his own term: "conterfet") of a nun and, as part of the process, he gave to her community " 7 weiszpfennig" and three engravings, probably of his own making. ${ }^{20}$ This is particularly intriguing because normally Dürer would not pay but rather charge one Philip guilder for a drawn portrait. Yet in this case the customer was the artist himself.

Because of this, and despite of his phrase "conterfet", Dürer's drawing is more likely to have been a kind of tronie, a careful study of an individual face made and kept by the artist with the aim of adapting it for a character in a future image. If that is so, the nun sat for Dürer because he thought she had an interesting face that would help him visualise, perhaps, that of a female saint. ${ }^{21}$ As was reasonable, he paid his sitter, not the reverse, because he got to keep the portrait. From the nun's point of view, it must have seemed an easy way of

19 Often portraits of women were commissioned by husbands, male relatives or lovers but affluent women certainly also commissioned portraits of themselves and their families. For a sense of the wide range of patrons and motivations behind the making of portraits of both men and women, see Lorne Campbell, Renaissance Portraits: European PortraitPainting in the 14th, 15th and 16 th Centuries (New Haven and London: Yale University Press, 1990), 139, 141-142, 144-145 and 193-218.

20 Jan G. van Gelder, "Sister Metzgen, a Portrait by Dürer," Master Drawings 9 (1971): 154-159.

21 Van Gelder, “Sister Metzgen," 158. 


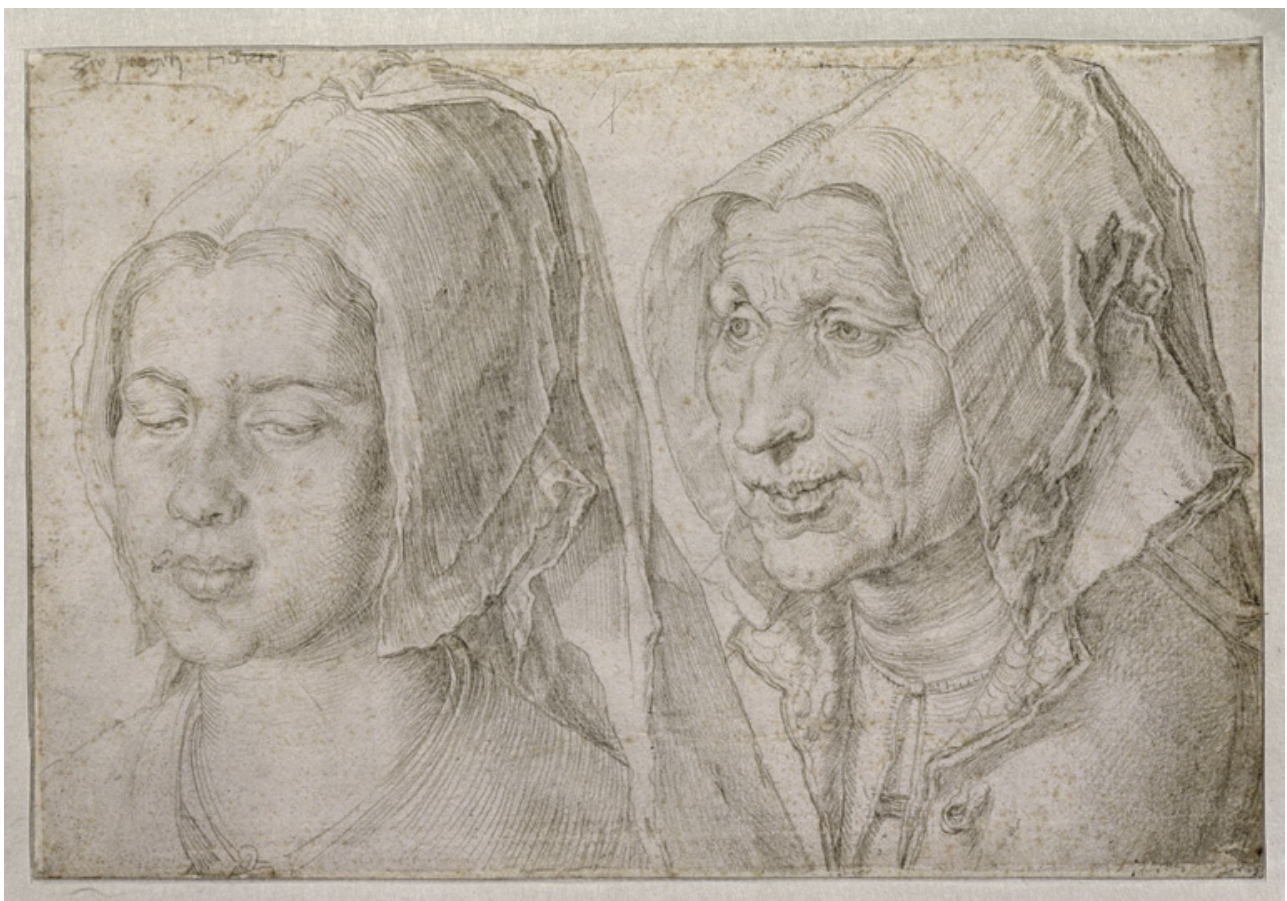

FIGURE 4.8 Albrecht Dürer, Metzgen and an older woman, c. 1520, Musée Condé, Chantilly

earning a bit of money and garnering some nice pictures for her community. So it was still a fairly straightforward exchange of money for artistic labour and subsequent ownership of the resulting image; and that must have been so for most early modern nuns' portraits. Even so, there is one extant Netherlandish example demonstrating that the transaction could be devotional as well as financial, a group portrait of Augustinian nuns with the clear injunction "By God's will, pray for the painter of this ...."22

It may be that Dürer's drawing still survives (Fig. 4.8). If the young veiled woman on the left with downcast eyes is indeed the Antwerp nun that he portrayed, the artist's inscription identifies her as Metzgen, a diminutive of Matilde or Mechtild. ${ }^{23}$ The drawing certainly fits with Dürer's own sense of what makes a portrait. In it, he attended with exaggerated care to Metzgen's features, delineating uneven brows, a neat but slightly bulbous nose, full lips and somewhat chubby chin. At the same time, her demurely lowered gaze

22 "Om Gods Wil bidt voor den Schilder deser [...]" (my ellipsis). Vandenbroeck, Hooglied, 256 (catalogue no. 201).

23 Van Gelder, “Sister Metzgen," 156. 
and general features may perhaps be detected in certain later drawings where Dürer depicts St Anne and the Virgin Mary. ${ }^{24}$ It is also worth noting that, either before or after drawing Metzgen, Dürer deliberately juxtaposed her face with that of a much older woman in similar garb, exploring the contrast between a youthful and a mature female face.

If this drawing is indeed of a nun named Metzgen and if it is that referenced in Dürer's account book, the work bears witness to a rather charged portrait encounter, at least if viewed through the lens of early modern sexual morality. In return for payment, a young Antwerp nun permits a traveller from Nuremberg - a married man perilously far from home - to gaze intently at her face, intently enough to delineate her features in detail. Of course, Dürer was a virtuoso draughtsman as well as an acute businessman and so would have worked with despatch. ${ }^{25}$ But it would still have taken time to set out in metalpoint the soft shading of her cheeks and the delicate folds in her headdress; the precise nature of the drawing implies a fairly prolonged sitting.

In any case the entry in Dürer's account book implies that a close portrait encounter between a nun and a visiting male artist was still possible in the early 1520 . Such transactions must have become rather more problematic after the Council of Trent's clamour for the strict enclosure of nuns in 1563. It is worth quoting the relevant passage at length, to convey its emphatic tone:

The holy Synod [...] enjoins on all bishops [...] that, by their ordinary authority, in all monasteries subject to them, and in others, by the authority of the Apostolic See, they make it their especial care, that the enclosure of nuns be carefully restored, wheresoever it has been violated, and that it be preserved, wheresoever it has not been violated; repressing, by ecclesiastical censures and other penalties, without regarding any appeal whatsoever, the disobedient and gainsayers, and calling in for this end, if need be, the aid of the Secular arm. [....] But for no nun, after her profession, shall it be lawful to go out of her convent, even for a brief period, under any pretext whatever, except for some lawful cause, which is to be approved of by the bishop; any indults and privileges whatsoever notwithstanding.

And it shall not be lawful for any one, of whatsoever birth, or condition, sex, or age, to enter within the enclosure of a nunnery, without the permission of the bishop, or of the Superior, obtained in writing, under

24 Van Gelder, "Sister Metzgen," 158.

25 A good sense of Dürer's business acumen may be gained from Jane C. Hutchison, Albrecht Dürer: A Biography (Princeton: Princeton University Press, 1990), 97-105 and passim. 
the pain of excommunication to be ipso facto incurred. But the bishop, or the Superior ought to grant this permission in necessary cases only; nor shall any other person be able by any means to grant it, even by virtue of any faculty, or indult, already granted, or that may hereafter be granted. ${ }^{26}$

As far as Trent was concerned, nuns should stay within their convents. Any contact with the outside world should be carefully regulated; the Council evidently thought that female chastity was easily compromised. After Trent, at least in theory, cloistered nuns could only engage actively with those of the outside world through the grille in their parlour. ${ }^{27}$ In turn, this must have made portrait encounters between nuns and male artists rather more complicated than that between Dürer and the Antwerp nun, even if it is possible to observe a face carefully through a convent grille. Perhaps this is one reason why Rubens took such care to convey chastity in his portrait of Ana Dorotea (Fig. 4.6).

As is well known, and as noted in the introduction to this volume, in practice enclosure varied enormously and, by extension, this must also have applied to conventual portrait encounters. Of course, beguines and klopjes were never formally enclosed. Moreover, some formally professed nuns bluntly refused to accept claustration, claiming it a new-fangled imposition. ${ }^{28}$ Others deliberately circumvented it, sometimes in amazingly brave (or foolhardy, depending on one's attitude to risk) and ingenious ways, whilst others again embraced it as a special path to virtue and sanctity. ${ }^{29}$ The sheer diversity of how religious women dealt with enclosure is one small but very clear example

26 J. Waterworth, ed. and trans., The Council of Trent: The Twenty-Fifth Session. The canons and decrees of the sacred and oecumenical Council of Trent (London: Dolman, 1848), 240242 (my ellipses).

$27 \quad$ For a thorough and helpful discussion of how Trent impacted on convent architecture in Naples, see Helen Hills, "The Veiled Body: Within the Folds of Early Modern Neapolitan Convent Architecture," Oxford Art Journal 27 (2004): 271-29o and also Helen Hills, Invisible City: the architecture of devotion in seventeenth-century Neapolitan convents (Oxford: Oxford University Press, 2004).

28 The tensions inherent in the coming of claustration are admirably described in Elizabeth A. Lehfeldt, "Discipline, Vocation and Patronage: Spanish Religious Women in a Tridentine Microclimate," Sixteenth Century Journal 30 (1999): 1009-30 and also in Silvia Evangelisti, 'Art and the Advent of Clausura: The Convent of Saint Catherine of Siena in Tridentine Florence' in Suor Plautilla Nelli, 1523-1588: First Woman Painter of Florence, ed. Jonathan Nelson (Florence: Cadmo, 2000), 67-82.

29 An excellent and wonderfully entertaining account of just how daring and inventive nuns could be when trying to circumvent enclosure is Craig Monson, Nuns Behaving Badly: Tales of Music, Magic, Art, and Arson in the Convents of Italy (Chicago: University of Chicago Press, 2010). 
of the complex issues surrounding female agency in the early modern period, as discussed in the present volume by Martha Howell.

In general, the Discalced Carmelite nuns embraced enclosure. They were one of the most prestigious female orders in the early modern southern Netherlands, whence they had been invited by the Infanta Isabella Clara Eugenia. Their first foundation was next to her palace in Brussels and the nuns generally came from local elite families. ${ }^{30}$ It is also worth noting that, when this group of nuns moved from their temporary home into their convent by the Brussels palace in 1611, they processed heavily veiled, deliberately shielding their faces and bodies from any curious or impertinent gazes from the general public. $^{31}$ At least in the post-Tridentine southern Netherlands, St. Teresa's daughters served as an important benchmark for female monastic virtue and, as the Brussels sisters ostentatiously demonstrated in 1611, they observed strict enclosure. It is unlikely that any of them would have deigned to unveil their faces simply to help a male artist envisage sanctity.

That said, the visibility of cloistered nuns' faces varied considerably. This is apparent from a travel description penned in 1663 by the young English botanist Philip Skippon, son of a Puritan military officer. Skippon avidly recorded the exact amount of visual contact he was permitted in the convents of France and the Low Countries. For example, in Gravelines he noted that the English Franciscan nuns "live very strictly, and never see the face of any man; the bars were of iron that we discours'd through."32 In Dunkirk, he also visited the English Franciscan sisters: "we went into their chapel, and then through a wooden grate we had liberty to see one or two of them in their habits, but would not discover their faces." ${ }^{33}$ The English Benedictines of the same city were less strict: "being admitted into a parlour, a curtain was drawn, and we had freedom to see and discourse with the ladies; about five or six giving us the entertainment of their company through an iron grate". ${ }^{34}$

Despite these variations it remains safe to assume that, in the postTridentine period, in certain contexts it was problematic for male artists

30 For a general account of the Infanta Isabella's engagement with this order, see Angel Manrique, La Venerable Madre Ana de Iesus (Brussels: Lucas de Meerbeeck, 1632), 65-79 (second order of pagination) and passim.

31 Manrique, La Venerable Madre Ana, 78 (second order of pagination).

32 Philip Skippon, 'An account of a journey made thro' part of the Low-Countries, Germany, Italy and France,' in A collection of voyages and travels, some now printed from original manuscripts, others now first published in English ..., (London: Printed by assignment from Messrs. Churchill, 1732), 362. My thanks to Sarah Moran for drawing this wonderful source to my attention.

33 Skippon, 'An account', 362.

34 Skippon, 'An account', 363. 


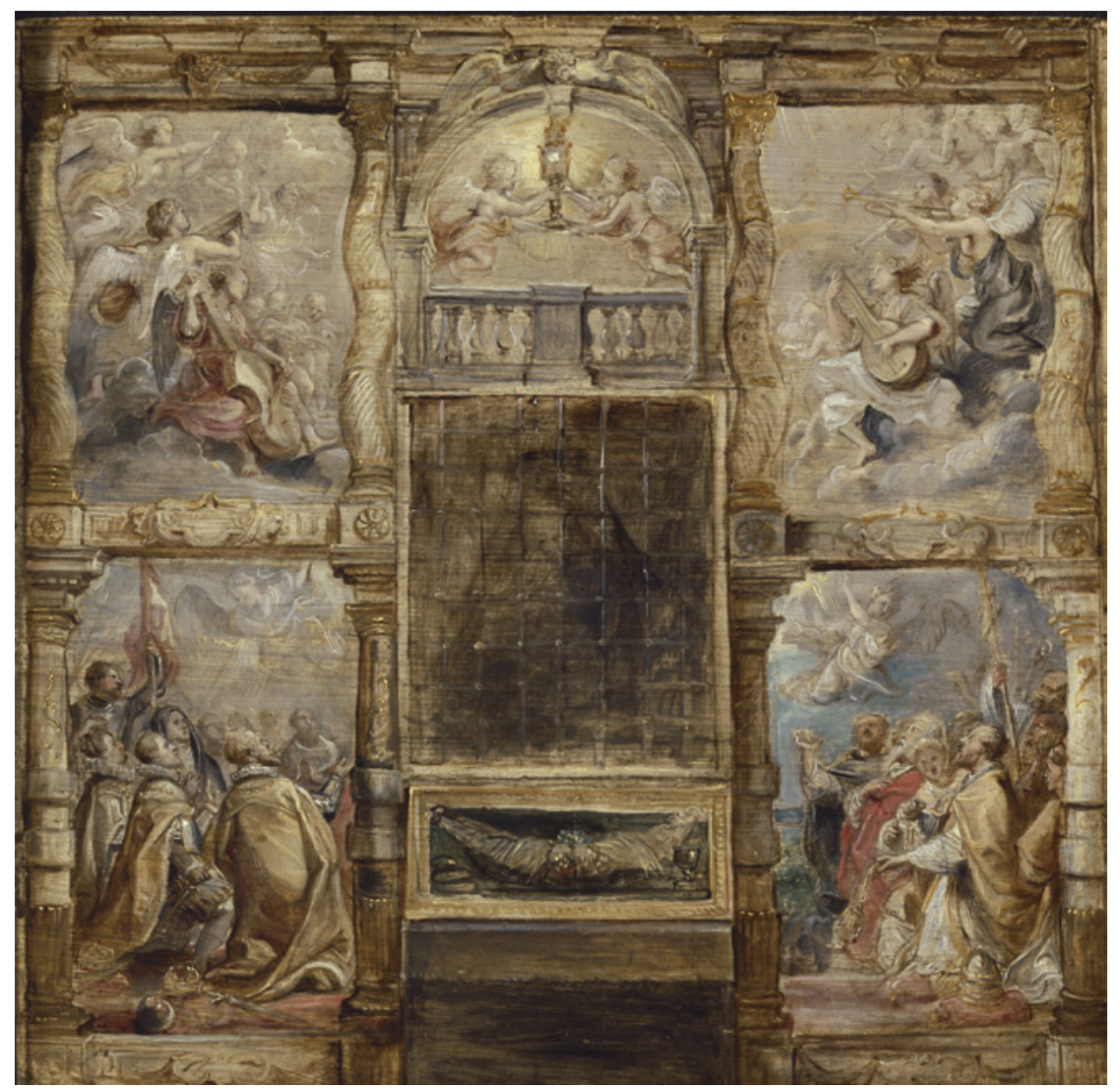

FIgure 4.9 Peter Paul Rubens, The Adoration of the Eucharist, c. 1626, Art Institute, Chicago

to portray cloistered nuns. Further circumstantial evidence comes from a poignant sketch in which Rubens tried to visualise from his home in Antwerp how his tapestry designs would work in the convent of the Descalzas Reales in Madrid (Fig. 4.9). ${ }^{35}$ At the centre there is a grille; through it one glimpses the ghostly outline of a Franciscan nun. It may be that this spectral nun is somehow related to Rubens's memories of painting Ana Dorotea in Madrid nearly a decade earlier (Fig. 4.6); she was, after all, a member of the strictly enclosed Descalzas Reales. Although this is perhaps a little fanciful, Rubens's tapestry sketch is suggestive of the practical difficulties involved in having to gaze through a grille at a heavily veiled cloistered nun with the expectation of producing a functioning likeness. In addition, Rubens's Catholic faith surely

35 Nora de Poorter, The Eucharist Series - Corpus Rubenianum Ludwig Burchard, part II (London: Harvey Miller, 1978), vol. 1, 258-262. 
bade him respect a nun's vow of chastity and, by extension, her right not to be subjected to unnecessarily extensive male scrutiny; a right that, as Skippon noted, was fiercely defended by her Franciscan sisters in Gravelines and Dunkirk. ${ }^{36}$ That is to say, Rubens's portrait encounter with Ana Dorotea may have felt discomfiting for both.

For cloistered nuns the problem was much less intense if the portraitist was a close male relative, as in the case of de Champaigne's portraits of his daughter Catherine at Port-Royal. He was also permitted to paint the abbess, Angélique Arnauld, despite her well-known inflexible attitude to contact between her nuns and their male relatives and her more general mistrust of men. ${ }^{37}$ This indicates that a male artist might more easily have access to conventual portraiture if he had a female family member within the walls.

On the other hand, not all early modern portrait painters were men; some of them were even nuns themselves. This included Louise-Hollandine of the Palatinate, Abbess of the Cistercians at Maubuisson near Paris, who in childhood had been taught to draw by Gerard van Honthorst (Fig. 4.10). ${ }^{38}$ Admittedly, Louise-Hollandine was in many ways exceptional. The daughter of Frederick, Count Palatine, and Princess Elizabeth Stuart, she had been raised a Calvinist in The Hague and was first received into the Roman Catholic faith in the convent of the English Discalced Carmelites in Antwerp in $165^{8}$. Like Queen Christina of Sweden, she was a trophy convert with a range and depth of education inaccessible to the majority of early modern women. Even so, Louise-Hollandine remains one well-documented early modern example of a nun with painterly skills (although her oeuvre still needs to be mapped out in proper detail). Another, even better documented example is

36 Rubens was a member of one of the Jesuit Sodalities in his home city of Antwerp. In the handbook published for these Sodalities in 1610, 1615 and again in 1620 there are explicit instructions that sexual desires arising from contemplating creatures, people or paintings must be avoided because they are sinful. It is also sinful to make paintings that elicit such desires. [Willem de Pretere], Het Hantboexken der Sodaliteyt oft Broederschap van de H. Maeghet Maria Inghestelt inde Societeyt Iesu (Antwerp: Hieronymus Verdussen, 1615), $117-118$.

37 Francis Martin, Angélique Arnauld: Abbess of Port Royal (London: Macmillan and Company, 1876), 219-220. Despite its age this remains a very useful biography.

38 Christopher A. Kerstjens, "A Princely Painter: Princess Louise Hollandine of the Palatinate, Abbess of Maubuisson," Court Historian 4(1999):161-66. Something of Louise Hollandine's reputation may be gained from Niall MacKenzie, "Jane Barker, Louise Hollandine of the Palatinate and 'Solomons Wise Daughter', The Review of English Studies (New Series) 58 (2007): 64-72. 


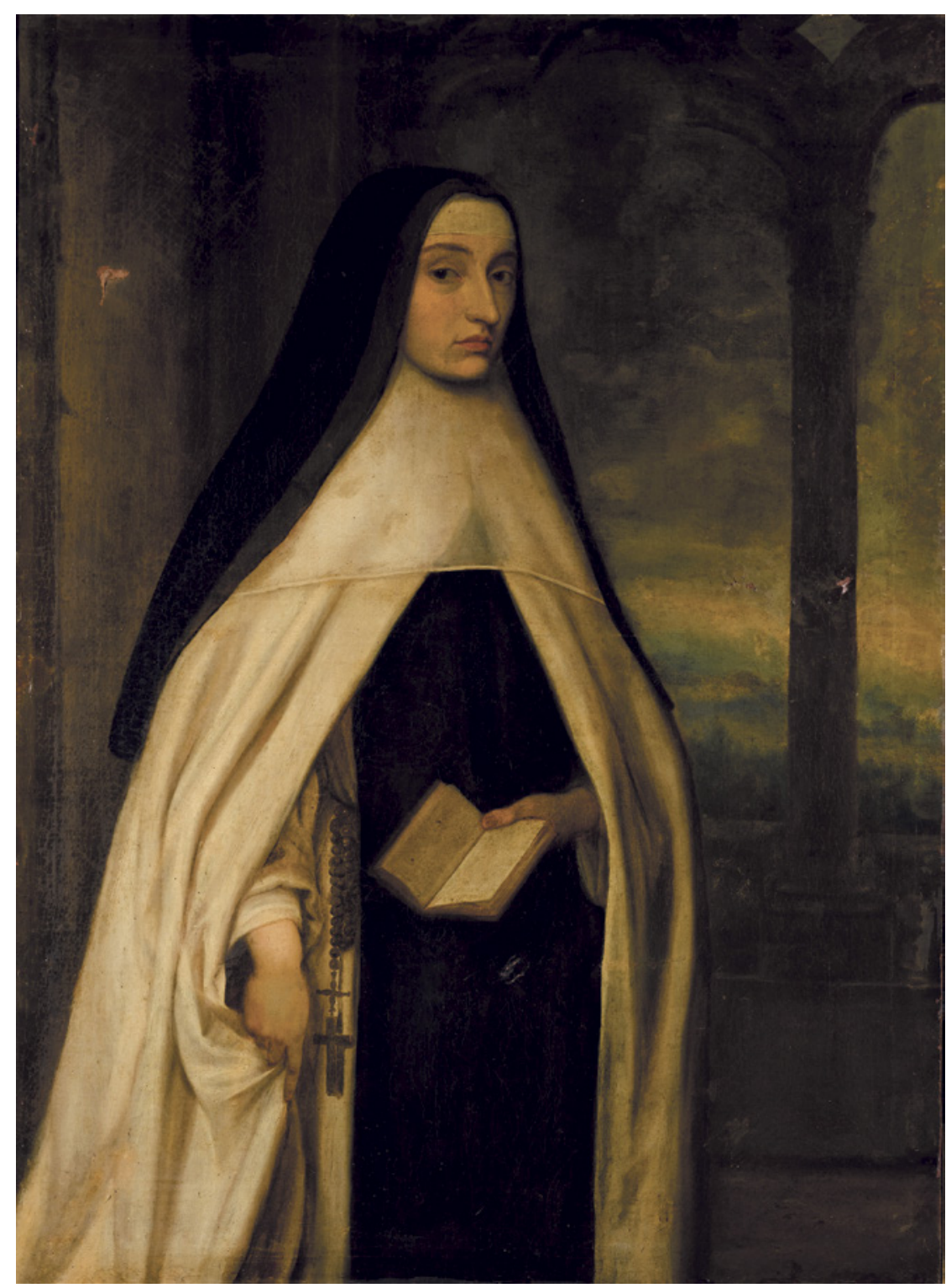

FIGURE 4.10 Louise-Hollandine of the Palatinate, Self-portrait, seventeenth century, present whereabouts unknown

the sixteenth-century Florentine nun Plautilla Nelli. ${ }^{39}$ It was surely perfectly in order for such painters to portray their monastic sisters. In fact, it may be the

39 See Jonathan Nelson ed., Suor Plautilla Nelli, 1523-1588: First Woman Painter of Florence (Florence: Cadmo, 2000). 
case that several early modern nuns' portraits were made within the walls; in Europe there is a long tradition of conventual painting dating back to medieval book illumination..$^{40}$ But there is a problem here: given how many of the nuns' portraits remain anonymous, it is hard to be conclusive about their authorship. The extent to which early modern nuns were also portraitists certainly needs more research.

Given all of this, it would seem that the often quite generic nature of early modern nuns' portraits may partly be rooted in the complex negotiations involved in conventual portrait encounters, especially when involving a male painter. Nuns and their portraitists had to navigate in some manner a cluster of tensions inherent in the deeply patriarchal post-Tridentine monastic ideals for women. Somehow, they had to bridge the gap between the cloister and the world, between the shielding veil and the openly revealed face.

One can only get so far by examining the surviving pictorial evidence. To gain further scholarly purchase on early modern nuns' portraits it is necessary also to attend to their functions, insofar as these can established. Some portraits were made for their sitters' families. This much is indicated by the number of early modern portraits of nuns that can still be found in country houses belonging to prominent English Roman Catholics. ${ }^{41}$

One good example is that of the Augustinian nun Anne Stonor, attributed to the French painter Jean-François de Troy, which hangs in her family home in Oxfordshire (Fig. 4.4).42 A smiling young woman faces the viewer, her blossoming face framed by her monastic coif and veil whilst the outline of her body is almost entirely obscured by her voluminous habit. In many ways this image falls within the generic ideal of youthful female beauty that Rubens also deployed in his portrait of Ana Dorotea. Again, this ideal is carefully tempered: Anne's portrait comes with a nose and a setting of the eyes that are sufficiently individualised to suggest that she is an actual person.

40 There is, for example, the excellent account provided in Jeffrey H. Hamburger, Nuns as artists: the visual culture of a medieval convent (London and Berkeley: University of California Press, 1997).

41 There is an extensive literature on English convents in the Low Countries. One of the most recent works is Laurence Lux-Sterritt, English Benedictine Nuns in Exile in the Seventeenth Century: Living Spirituality (Manchester: Manchester University Press, 2017); another helpful account is Walker, Gender and Politics in Early Modern Europe.

42 Oliver Garnett, ed., Stonor: Home of the Stonor Family for 850 Years (Stonor: Stonor Enterprises, 2010), 17 . 
Anne holds open a small book in her left hand while her right rests on a passage in a larger volume, next to which lie another two of the same size. The visible text at the top of the page allows the viewer to identify these books as St Augustine's City of God. Yet again this balances the individual with the generic, by suggesting scholarship of a delighted and highly dedicated kind combined with a clear, even didactic address to the audience. Perhaps we are to imagine that Anne is identifying for us the patristic origins of a passage in her small devotional book. In some ways, this portrait playfully subverts gendered pictorial norms: it is similar to Rubens's depiction of Ophovius insofar as it evokes a cerebral personality engaging directly with the viewer. Nevertheless, Anne's chastity is asserted much more forcefully. Her lower body is shielded behind a barrier far firmer than cloth: the books and the table located, not coincidentally, directly in front of her lower pelvis, implying that her chastity and scholarship are mutually dependent.

What might such a portrait have meant to Anne's family, a staunchly Roman Catholic dynasty who would endure several rounds of persecution in early modern England? It may have seemed fortifying, for several reasons. Most straightforwardly, it made a daughter, sister and aunt now living in distant Paris visible within her Oxfordshire family home. In this manner, the painting fits with an absolutely standard function assigned to portraiture in early modern Europe, that of making the absent seem present. ${ }^{43}$ Probably, Anne's picture played a mnemonic role; it kept her in the mind and bosom of her family, if only figuratively. Second, the portrait posits her apparent happiness in her vocation. Its depiction of cheerful but reassuringly chaste feminine scholarship was surely a comfort to a family who had sacrificed a great deal to remain faithful to Rome. ${ }^{44}$ From this follows the third reason, which hinges on Anne's evident prettiness. A face like hers - if she really looked like her portrait, that is - would have had a certain currency on the early modern marriage market. English Catholic families like the Stonors made a point of marrying their children to co-religionists of equal rank. ${ }^{45}$ The limited number of these in the British Isles must have meant that committing a pretty daughter to a distant cloister was, in effect, the alienation of a dynastic asset, a not inconsequential gift to the

43 Campbell, Renaissance Portraits, 193-198.

44 See Robert J. Stonor, Stonor: A Catholic Sanctuary in the Chilterns from the fifth century till today (Newport: R. H. Johns, 1951) and Sally Jordan, "Gentry Catholicism in the Thames Valley, 1660-1780," British Catholic History 27 (2004): 217-243. 
Church. ${ }^{46}$ Anne's portrait was also a reminder of the patronage that the Stonor family had extended to her order, evidence of a religious sacrifice perhaps made in the hope of gaining prayers and other spiritual favours for her family.

Similar arguments may be made about the early modern portrait at Burton Constable Hall in Yorkshire, showing an as yet unidentified nun of the Tunstall family who was an Augustinian in Louvain (Fig. 4.11), or that of Anne Bedingfeld at Oxburgh Hall in Norfolk, who was a Discalced Carmelite in Lier (Fig. 4.12) ${ }^{47}$ Significantly, the Bedingfeld portrait forms part of a seventeenth-century set that also includes married women of the family. ${ }^{48}$ Hanging, as they still do, at Oxburgh, this set of portraits make manifest the various dynastic and spiritual alliances enjoyed by the Bedingfelds in the years after the English Civil War. These familial images thus confirm Evangelisti's point that early modern portraits of nuns evince how their sitters would retain close links with their natal families even as they devoted themselves to religion.

It may be that Pieter Leermans's portrait of the Carmelite novice had a similar purpose (Fig. 4.5). Certainly, the smiling countenance recalls the portraits of Anne Stonor and sister Tunstall, both made for familial contexts (Fig. 4.4 and Fig. 4.11). Moreover, Leerman's portrait fits surprisingly well with the better documented profession portraits made of nuns in New Spain (compare, for example, with Fig. 4.1); one indication that Córdova may be mistaken in assuming that this particular type of imagery was a colonial phenomenon. At the same time, the pallor of the young woman might imply that the portrait is posthumous, a treasured relic of a daughter or sister who had died in the odour of sanctity around the time of her profession.

At least judging by the surviving English examples, some early modern nuns' portraits had distinctly dynastic purposes. They made absent family members present. To fit with this function, nuns' portraits for familial consumption involved a delicate pictorial balancing act, combining individualising characteristics with a more generic ideal of cheery yet chaste youthful female beauty. In this, they follow a pattern which may also be observed in the idealising portraits of Stuart court beauties produced by painters such as Anthony van Dyck

46 This point is ably made in Lux Sterritt, English Benedictine nuns, 68.

47 See the very useful 'Who were the nuns?' website: https://wwtn.history.qmul.ac.uk/ search/search.php?uid $=\&$ quote $=$ no\&given $=\&$ religion $=\&$ surname $=$ Tunstall\&variants $=$ on\&cid $=0 \&$ sdate $=0 \&$ edate $=0 \& l o c=($ on the Tunstall family $)$ and https: $/ /$ wwtn.history .qmul.ac.uk/search/search.php?uid =\&quote=no\&given=Ann\&religion=\&surname=Be dingfield \&variants $=0$ \& $\&$ cid $=0 \&$ sdate $=0 \&$ edate $=0 \& l o c=($ on Anne Bedingfeld $) ;$ both last accessed 22 May 2017. 


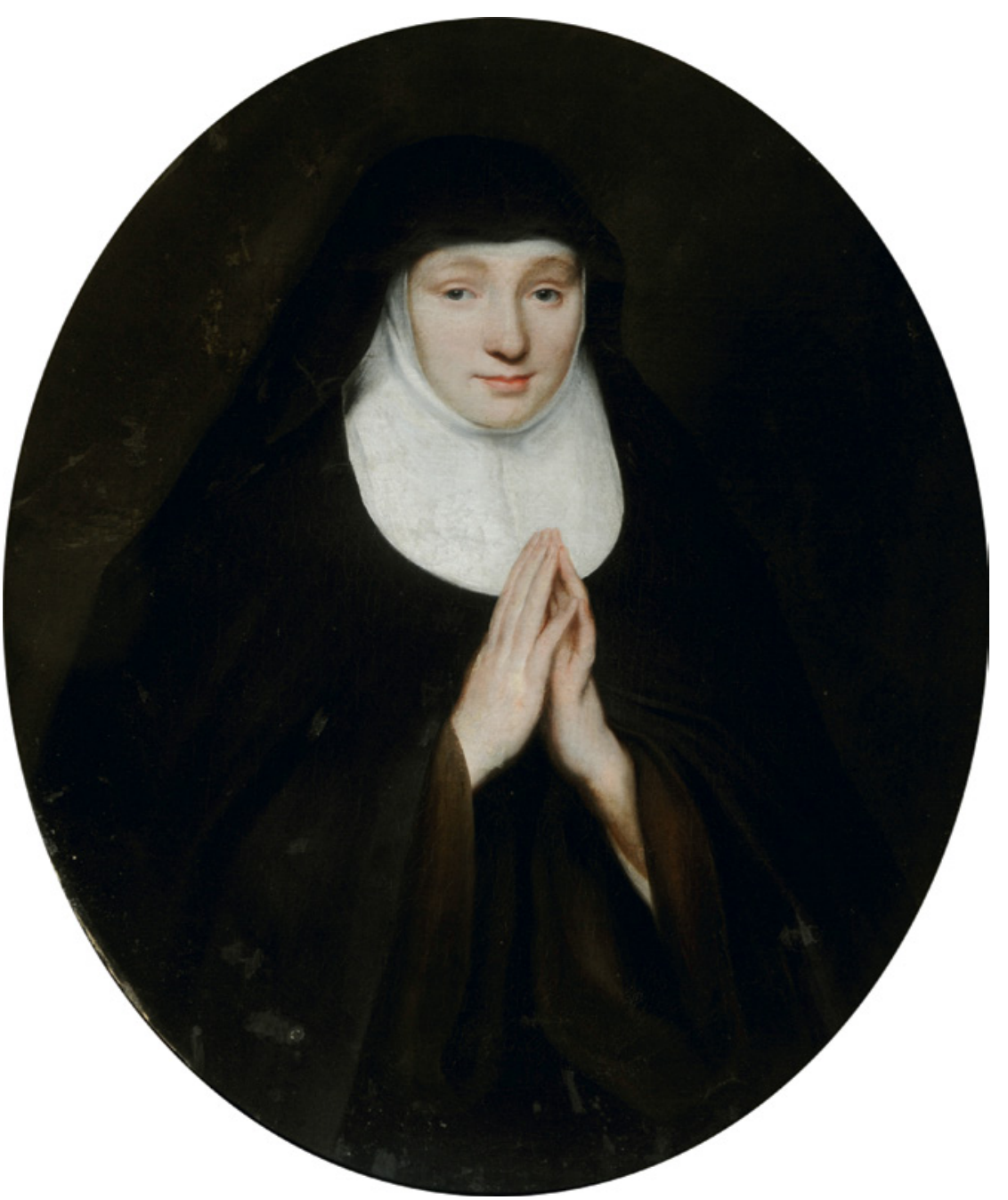

FIGURE 4.11 Anon. Flemish artist, Ann, Mary or Cecily Tunstall, early to mid-eighteenth century, Burton Constable Hall, East Yorkshire

and Peter Lely. ${ }^{49}$ Yet, unlike this courtly tradition, the familial portraits of nuns discussed here both marked and were embedded in a broader and rather fluid cultural zone, that which constituted the north-western European frontier of Roman Catholicism.

49 On this tradition, see Catherine MacLeod and Julia Marciari Alexander, eds., Painted Ladies: Women at the Court of Charles II (London: National Portrait Gallery, 2001). 


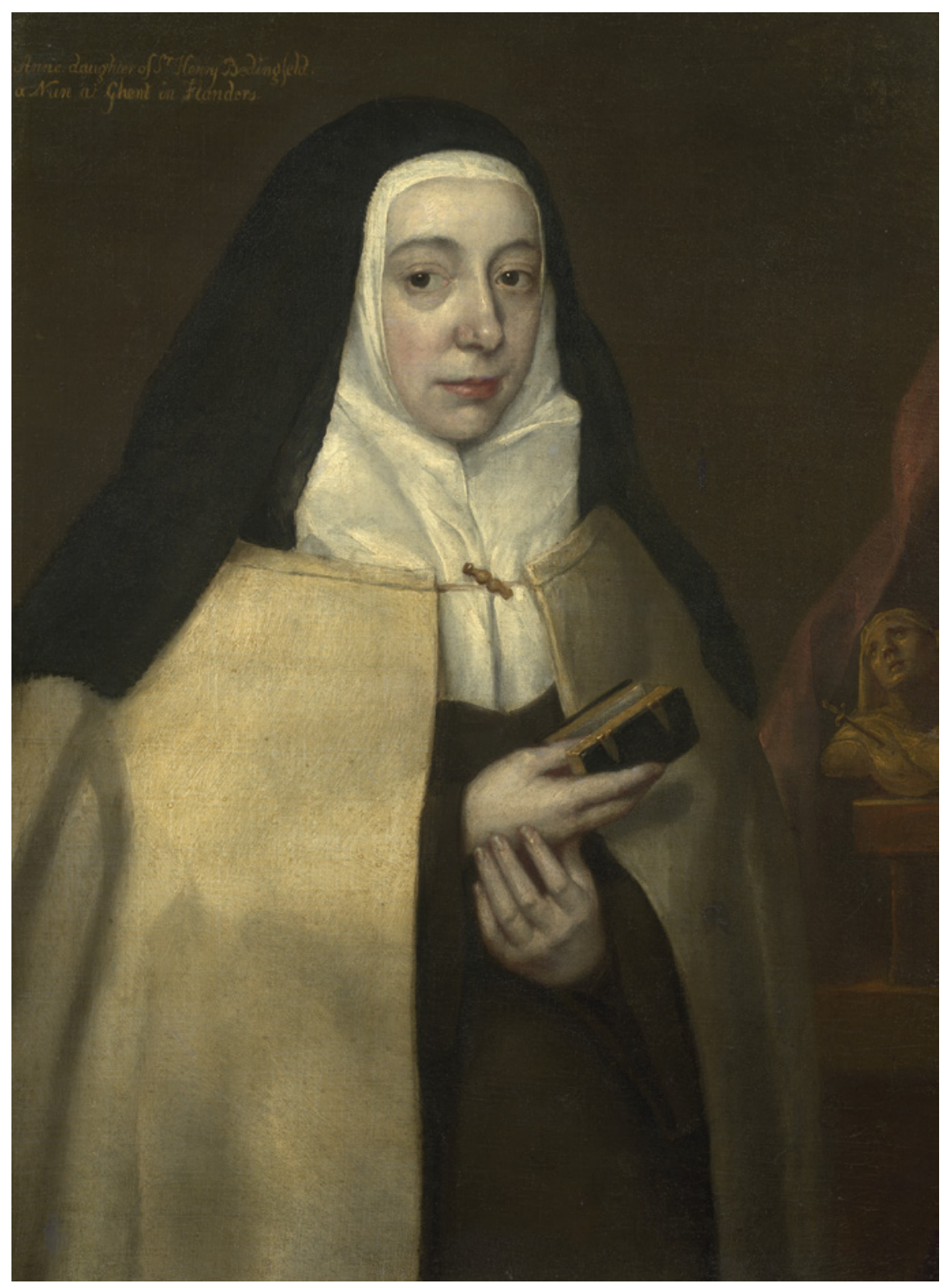

FIGURE 4.12 Anon. Flemish artist, Anne Bedingfeld, c. 168o, Oxburgh Hall, Norfolk 
Not all portraits of nuns were produced for families; at least in the Netherlands it seems that they often hung in convent parlours. This is suggested, for example, in the description of a visit to the English Discalced Carmelite convent in Antwerp written by another traveller, the Scottish Calvinist Thomas Penson, in 1687: "At the gate I was let in by a servant who directed me up one pair of stairs, which led me into a fair light chamber (adorned with the pictures of many devout women). On the one side thereof was a large double iron grate and by it hung a cord, with which I was ordered to ring a bell ..." 50 If these pictures "of many devout women" were portraits, they were part of the nuns' self-representation, one way of addressing the outside world, and not just the devout laity but also visiting Protestants and other sceptics.

That this was so is confirmed by an entry in the accounts of the Premonstratensian nuns of Sint-Catharinadal, one of the few Netherlandish convents to weather intact the many religious and political upheavals of the early modern period. In 1681 the nuns' confessor was entrusted with commissioning six portraits from one Master Sommeren in Antwerp, three of which were of confessors, the other three of nuns. ${ }^{51}$ The purpose of the nuns' portraits is clearly stated: "So as to give the Beggars [i.e. Calvinists] occasion to speak of the antiquity and nobility of our convent, these little nuns hang in the parlour".52 Evidently these nuns' portraits also had a mnemonic role to play. They were reminders of past glories meant to prompt parlour conversations with and amongst potentially hostile visitors.

Why did the nuns of Sint-Catharinadal feel that they needed such portraits for their parlour? To explore this question, it is helpful first to sketch out a little more of their circumstances. Their convent had been founded in 1271 and from 1295 onwards the nuns resided in the city of Breda, which was eventually to become one of the many domains of the Orange-Nassau family. Later, during the Eighty Years' War (1566-1648), Breda changed hands several times and, as one would expect, when it fell under Protestant domination the nuns of SintCatharinadal were subject to various forms of harassment. For example, in 1591

50 Thomas Penson, 'Penson's Short Progress into Holland, Flanders and France, with Remarques', 1687, Edinburgh, National Library of Scotland, Ms 3003. Here quoted after C. D. van Strien, "Recusant Houses in the Southern Netherlands as seen by British Tourists, c. 1650-1720," Recusant History 20 (1991): 495-511, 500, ellipsis added.

$5^{1} \quad$ It has not been possible to identify this painter so far.

$5^{2}$ 'Om aen de geuse occasie te geven om te spreecken van de autheijt en edelheijt van ons clooster hangen de nonnekens in 't spreeckhuijs.' Here quoted after Sponselee-de Meester, Het Norbertinessenklooster, 171. 
their church was confiscated and the sisters had to worship in a small chapel. Their property was gradually encroached upon until 1625 , when Breda fell to the Habsburg armies from the Catholic south and all sequestered monastic goods were returned to their former owners. Then, in 1637, Breda returned to Protestant domination. Having learnt their lesson, the Premonstratensian sisters vocally proclaimed the patronage of the Orange-Nassau family and thus were able to hold on to some of their privileges and most of their property. However, by 1646 their situation had become so difficult that they decided to leave Breda temporarily, settling in a small country manor near Oosterhout. In 1672 the nuns returned triumphantly to Breda under the impression that Orange-Nassau patronage would guarantee their safety. Their hopes were dashed only seven years later when, under severe Protestant pressure, they had to return to their country manor for good. There, with grudging Orange-Nassau support, they gradually recovered from their misfortunes. ${ }^{53}$

The three portraits for the parlour at Oosterhout were therefore commissioned shortly after a period of great turbulence by and for a community of nuns who had lived through considerable Calvinist bullying. By 1681 they very much needed their Protestant neighbours to respect the "antiquity and nobility" of their convent; their very survival depended on it. Accordingly, the three portraits were not of living sisters but rather of three prominent fifteenthcentury members of the Sint-Catharinadal community: Odilia of Nassau (Fig. 4.13), Elizabeth of Breda and of Leck (Fig. 4.14) and Machtild of Polanen (Fig. 4.15). All three were related to the Orange-Nassau family. Machtild was an aunt of Johanna of Polanen, Lady of Breda and Den Leck, whose marriage to the impoverished German Count Engelbrecht I of Nassau-Dillenburg had brought him substantial landholdings in the Low Countries; these would form the basis of the dynasty's future wealth. ${ }^{54}$ For his part, Engelbrecht was a direct ancestor in the male line of the current Prince of Orange, Stadhouder of Holland and Lord of Breda, the staunchly Calvinist William III, who from 1689 onwards also became King of England and Scotland. Meanwhile, Odilia of Nassau was Engelbrecht I's grandchild, daughter of his son Count Jan IV of Nassau-Dillenburg, also a direct ancestor of the current Prince of Orange. ${ }^{55}$ Elizabeth of Breda and of Leck is harder to identify but she may have been an illegitimate daughter of Johanna of Polanen's father and she is identified as a

53 The above paragraph is based on Sponselee-de Meester, Het Norbertinessenklooster, 160-190.

54 On Machtild and Johanna, see V. Paquay, "De stichting van de Wendelinuskapel te Breda," Jaarboek De Oranjeboom 36 (1983): 1-34, especially 4-7.

55 On Odilia of Nassau, see http://resources.huygens.knaw.nl/vrouwenlexicon/lemmata/ data/OdiliavanNassau, last visited 22 May 2017. 


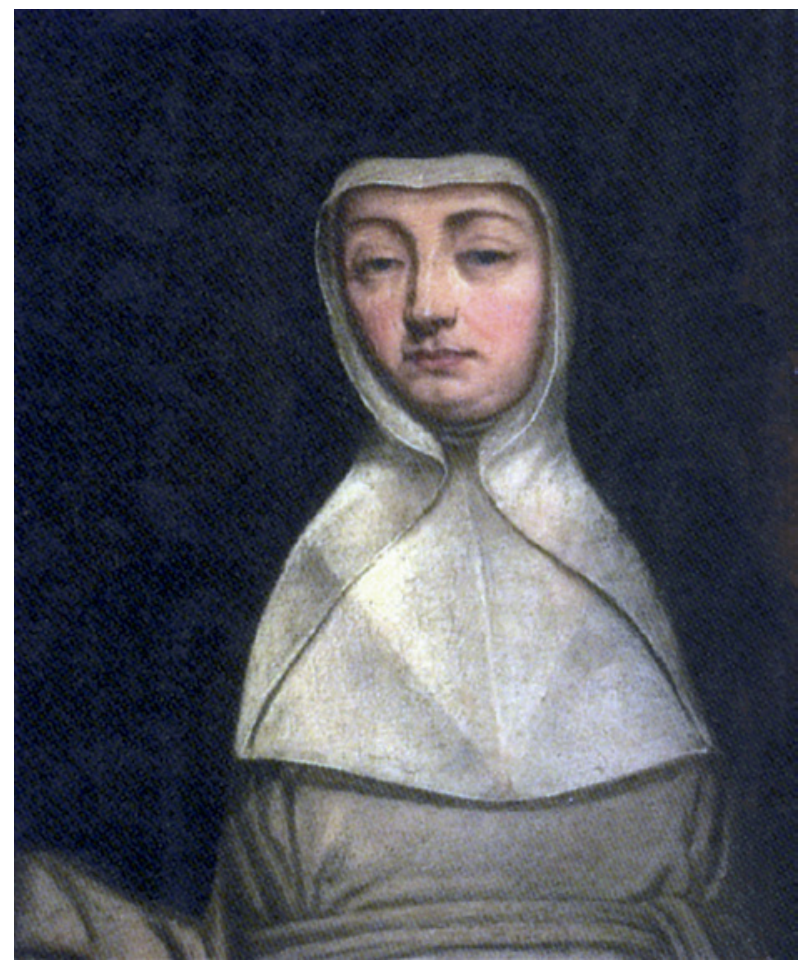

FIGURE 4.13 Master Sommeren, Odilia of Nassau, 1681, Sint-

Catharinadal, Oosterhout

prioress of Sint-Catharinadal on the frame of her portrait. Clearly, the point behind the three portraits was to remind all visitors to the parlour that SintCatharinadal was indeed a noble foundation, with ancient and enduring familial connections to the Orange court. These paintings also make the absent present, only in this case it is the distant and invisible past.

It may seem strange that the nuns of Sint-Catharinadal would endow such emphatically posthumous images with the status of portraiture, let alone with persuasive mnemonic power, but that is perhaps because we now understand the category of portraiture too readily within a photographic paradigm. Certainly, it is clear from the Premonstratensians' accounts that they saw these three images as having profound evidential weight, a point which is further supported by the actual portraits. The three paintings from the parlour at Sint-Catharinadal form a set: they have matching frames and follow the same severe pictorial format. They are obviously meant to work cumulatively, like the dynastic portraits at Oxburgh. In addition, all three have prominent inscriptions so that their sitters may be identified with confidence. This is just 


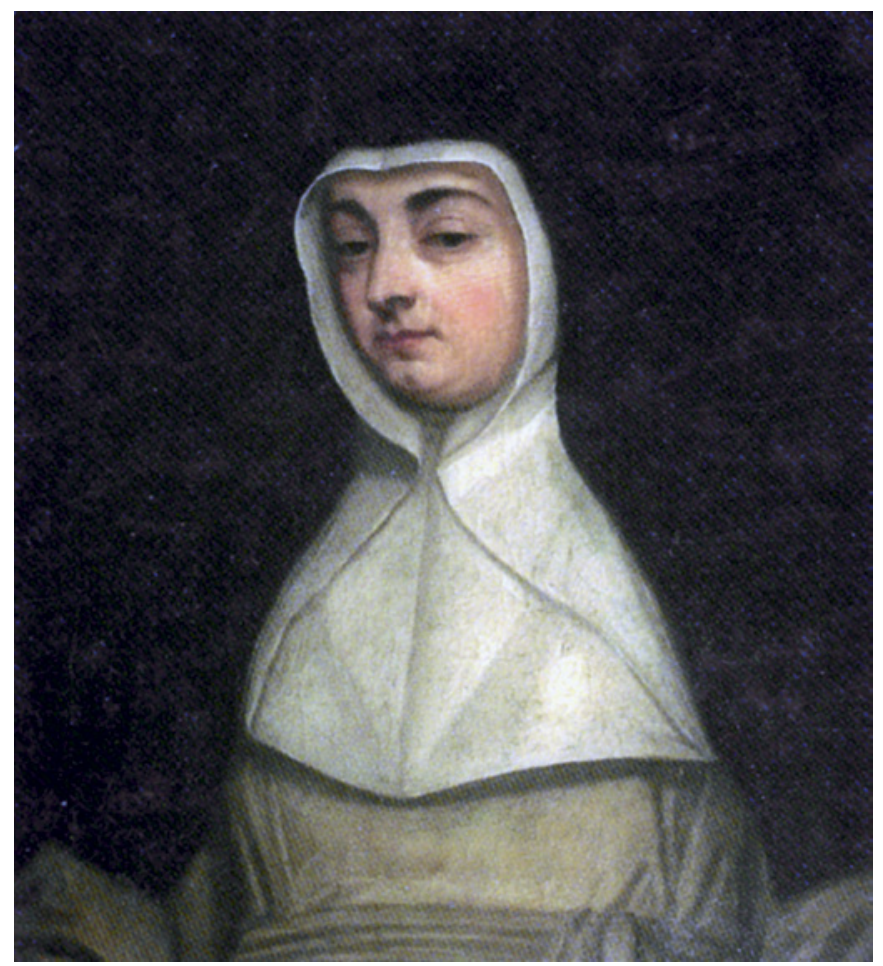

FIGURE 4.14 Master Sommeren, Elizabeth of Breda and of Lek, 1681, Sint-Catharinadal, Oosterhout

as well because two of the three have similar features, perhaps to suggest close kinship (Figs. 4.13 and 4.14). In any case, Master Sommeren of Antwerp could hardly have known what these medieval ladies looked like so he may have produced idealised images based on existing tronies or perhaps on medieval visual sources that are now beyond identification..$^{56}$ At least he did not have to peer through any grilles to do so.

On the other hand, there is a certain similarity between these nuns and SintCatharinadal's recently deceased, somewhat reluctant Calvinist benefactress, Amalia of Solms-Braunfels, Princess of Orange, grandmother of William III and until 1672 his main guardian (Fig. 4.16). This is most notable in the shared chubby chins. If that is so, for the well-informed early modern viewer these

56 Other painters active in early modern Antwerp certainly drew on such sources, including Antonio de Succa, who specialised in historical portraiture. Kristin L. Belkin, The Costume Books - Corpus Rubenianum Ludwig Burchard, part XXIV (Brussels: Arcade Press, 1980), $35^{-43}$. 


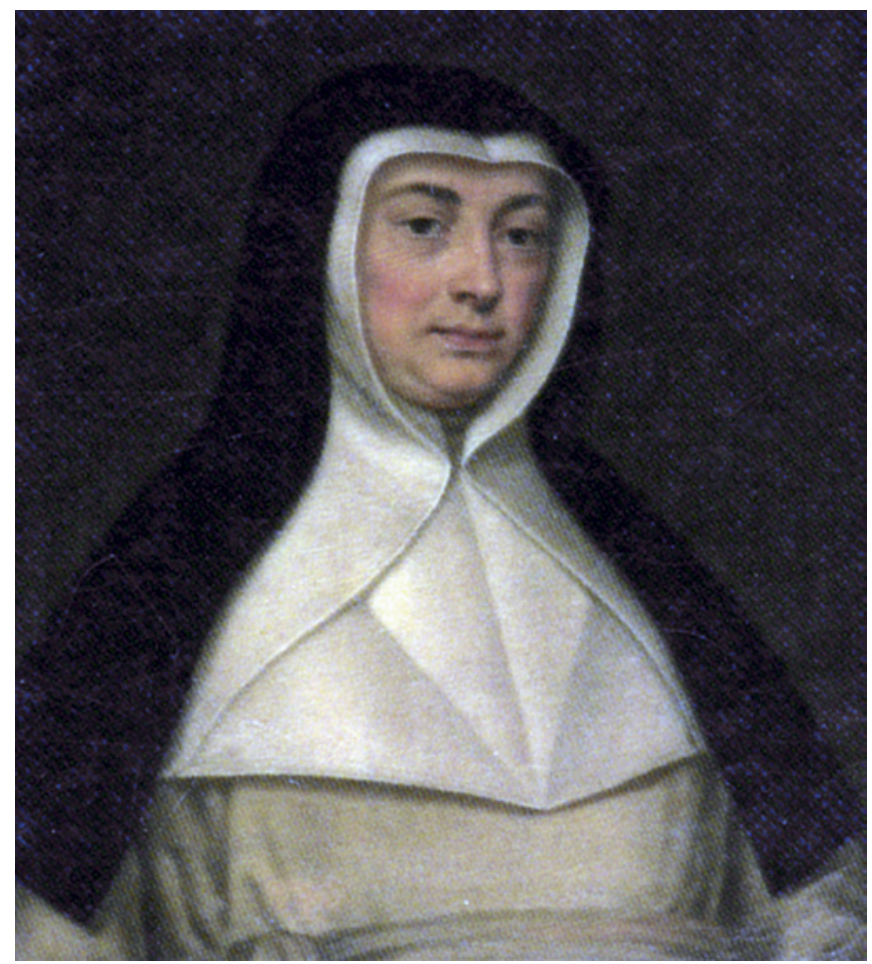

FIGURE 4.15 Master Sommeren, Machtild of Polanen, 1681, Sint-

Catharinadal, Oosterhout

nuns' portraits may have evoked present as well as past links with the Orange family - although it may equally be that both nuns and princesses were made to conform to idealising standards of female beauty, as was the case in England.

To complicate this even further, there is the fact that the image of Machtild of Polanen (Fig. 4.15) is far more individualised, most notably in the prominent cheekbones and the forcefully modelled nose with its broad nostrils and distinctly shaped septum. Maybe this image is explicitly based on one of the nuns at Sint-Catharinadal, perhaps even the prioress, who must have been involved in the portrait commission. If so, this would have lent further persuasive power to the portrait, literally figuring a living nun as an important Orange kinswoman, part of the dynasty that had brought them the bulk of their Netherlandish domains, including the Lordship of Breda.

Although this can only remain speculation, the painting of Machtild of Polanen demonstrates that early modern nuns' portraits were a highly flexible phenomenon, encompassing long deceased as well as living individuals. Such portraits need not be exact likenesses to come with persuasive evidential 


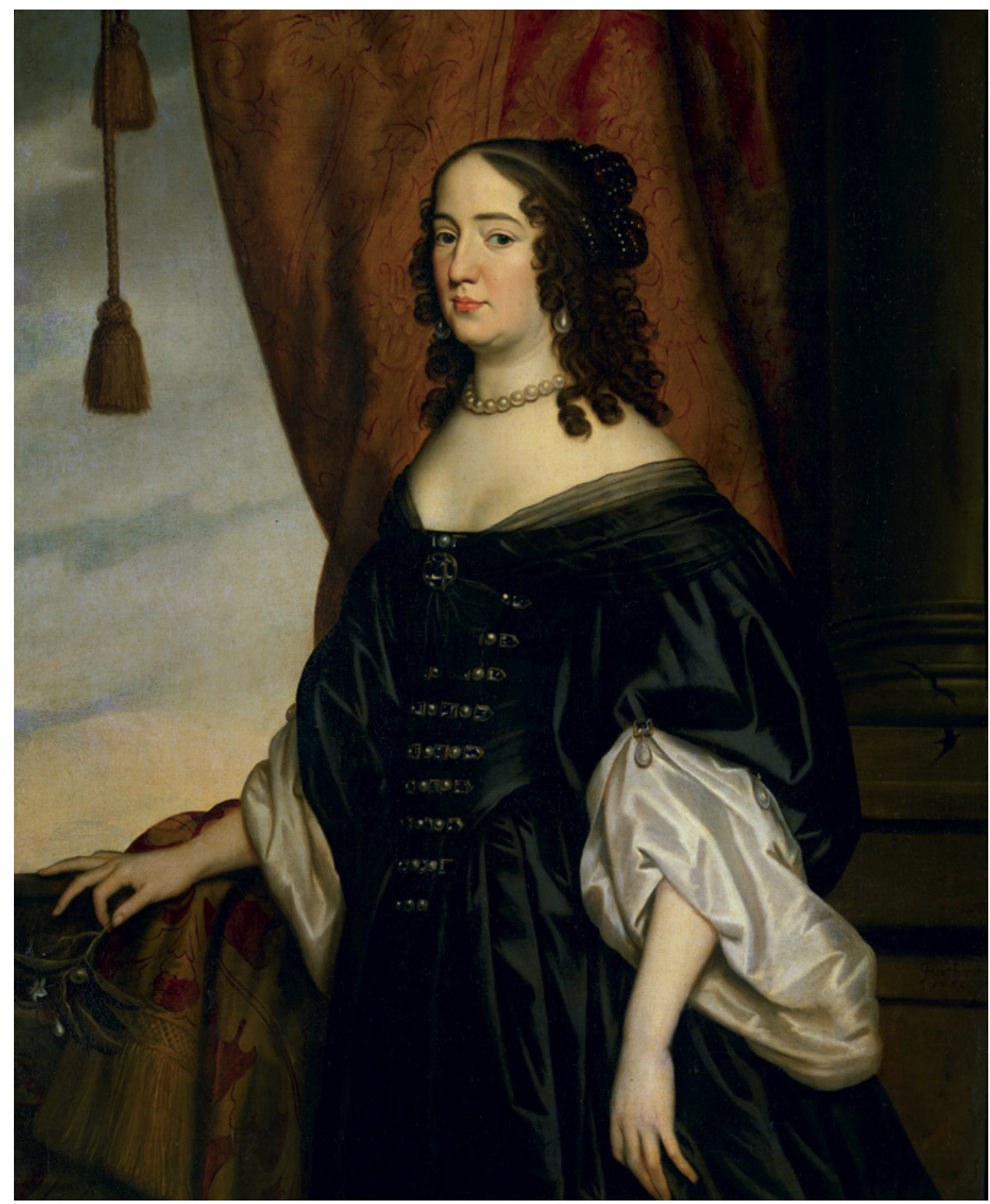

FIgURE 4.16 Workshop of Gerard van Honthorst, Amalia of Solms-Braunfels, Princess of Orange, 1650, Rijksmuseum, Amsterdam

potency; at least, this was so at Sint-Catharinadal. From this one may draw a number of conclusions. First, that in nuns' portraits the sense of an individual is sometimes less important than fitting in with familial or conventual strategies, concerns and identities. Second, that when hung in nuns' parlours such portraits came with their own temporalities, making present those who were long dead and thus helping to constitute a conventual community across time, neatly complementing the community as defined by the monastic space. 
Third, that nuns' portraits were thought to have certain powers, to be a form of advocacy, at least when hung in spaces frequented by Protestants and other sceptics.

This point may be explored further by returning to Penson's travel diary. He reports at length on the conversations he had with the English Discalced Carmelites in their Antwerp parlour. The first, a rather senior sister, came to the grille and enquired into his faith and, in response, "I truly answered that my education had been of the Reformed Protestant religion according to the Church of England, to which she was pleased to reply: 'I am sorry'". ${ }^{7}$ As this suggests, during such encounters the parlour was understood as a kind of missionary space, as is also evident in Skippon's travel account. ${ }^{58}$ That nuns used their parlours as a way of challenging Protestant scepticism becomes even clearer during Penson's subsequent encounter, worth quoting at length for the light it throws on this peculiarly conventual scenario:

There soon appeared (as an angel of light) a delicate, proper, young, beautiful lady, all in white garments and barefaced, whose graceful presence was delightful to behold and yet struck an awful reverence, considering she was devout and religious. And having paid my respects and fed my greedy eye a short moment on this lovely creature, I thus spoke: "Madam, may Heaven bless and enable you in your undertakings, which to us that are abroad in the world seem so hard and difficult. For we account it no less than being buried alive to be immured within the confines of these walls." To which she answered: "Sir, the world is much mistaken in their harsh censures of these religious houses, not considering the felicities we here enjoy in the service of God. And although for my part I may forsake this place when I please, being not but in the year of my noviceship, yet do assure you, Sir, I find so great satisfaction and contentment in this manner of life (being daily present with these devout women in holy exercises and prayers), that I would not change conditions with any princess or noble lady in the world."59

There is eroticism at play here. Penson unashamedly enjoys looking at the desirable yet unattainable young novice, who trumps his lust by inspiring "an

57 Van Strien, "Recusant Houses," 500.

$5^{8}$ See, for example, Skippon, 'An account', 362 and 370 , where nuns seek to sell touch relics to him or to persuade him that one of their number has been miraculously healed by the intervention of the Virgin Mary.

59 Van Strien, "Recusant Houses," 500. 
awful reverence". It is hard not to see this as a deliberate and probably wellworn strategy on behalf of the English nuns. First a senior sister identifies the Scottish visitor as a Protestant; then a pretty novice tries to persuade him of the blessings of enclosure. It is precisely because she is a novice that her lovely face may remain unveiled so as to support her missionary endeavour.

In fairness, it should be noted that this eroticism seems to be a recurrent feature of travel writings by early modern Protestant men; it is certainly also at play in young Skippon's dubious attention to nuns' faces, veils, habits, curtains and parlour grilles. Yet Penson's diary still suggests that a beautiful nun was thought to have special persuasive powers. Bearing the case of Sint-Catharinadal in mind, presumably this could be extended to her portrait when hung in the convent parlour. And, if that is so, this is a further explanation of why it is hard to identify the sitters of so many early modern nuns' portraits. They follow a relatively generic ideal of feminine beauty because - paradoxically - that was one way of endowing them with missionary potential. This is further supported by Mónica Díaz's account of nuns' portraits from the Americas, where she argues that these equally generic images have their roots firmly in their missionary context. ${ }^{60}$ Several of the early modern convents in the Netherlands were in similar situations, located in a liminal zone where nuns might regularly converse with and, hopefully, influence Protestant sceptics.

It is, however, important to underscore that conventional feminine beauty does not feature in all portraits of early modern nuns. There are some paintings that seem to be in deliberate contrast with the generic type discussed so far. One example is of an anonymous Benedictine nun portrayed in her sixty-seventh year, a work that in 1994 still hung in the great parlour of the abbey of Sint-Godelieve in Bruges (Fig. 4.17). ${ }^{61}$ The iconography is, in part, derived from a print of St Teresa of Avila, including the gaze fixed firmly on the crucifix as if deliberately eschewing contact with the viewer. ${ }^{62}$ There is little erotic charge here.

Instead the purpose was probably to celebrate the sitters' advanced age and, with it, to showcase her withdrawal from the sexual economy of the convent parlour into focused contemplation of her own approaching death. Thus, while the attributes of crucifix, skull and book are conventional, that is not the case for the carefully modelled face with its wrinkles and distinctive long

60 Díaz, "Native American Women and Religion," 205-231.

61 Vandenbroeck, Hooglied, 134 and 235 (catalogue 74).

62 Margit Thøfner, "How to Look Like a (Female) Saint: The Early Iconography of St Teresa of Avila' in Female Monasticism in Early Modern Europe: An Interdisciplinary View, ed. Cordula van Wyhe (Aldershot: Ashgate, 2008), 59-78. 


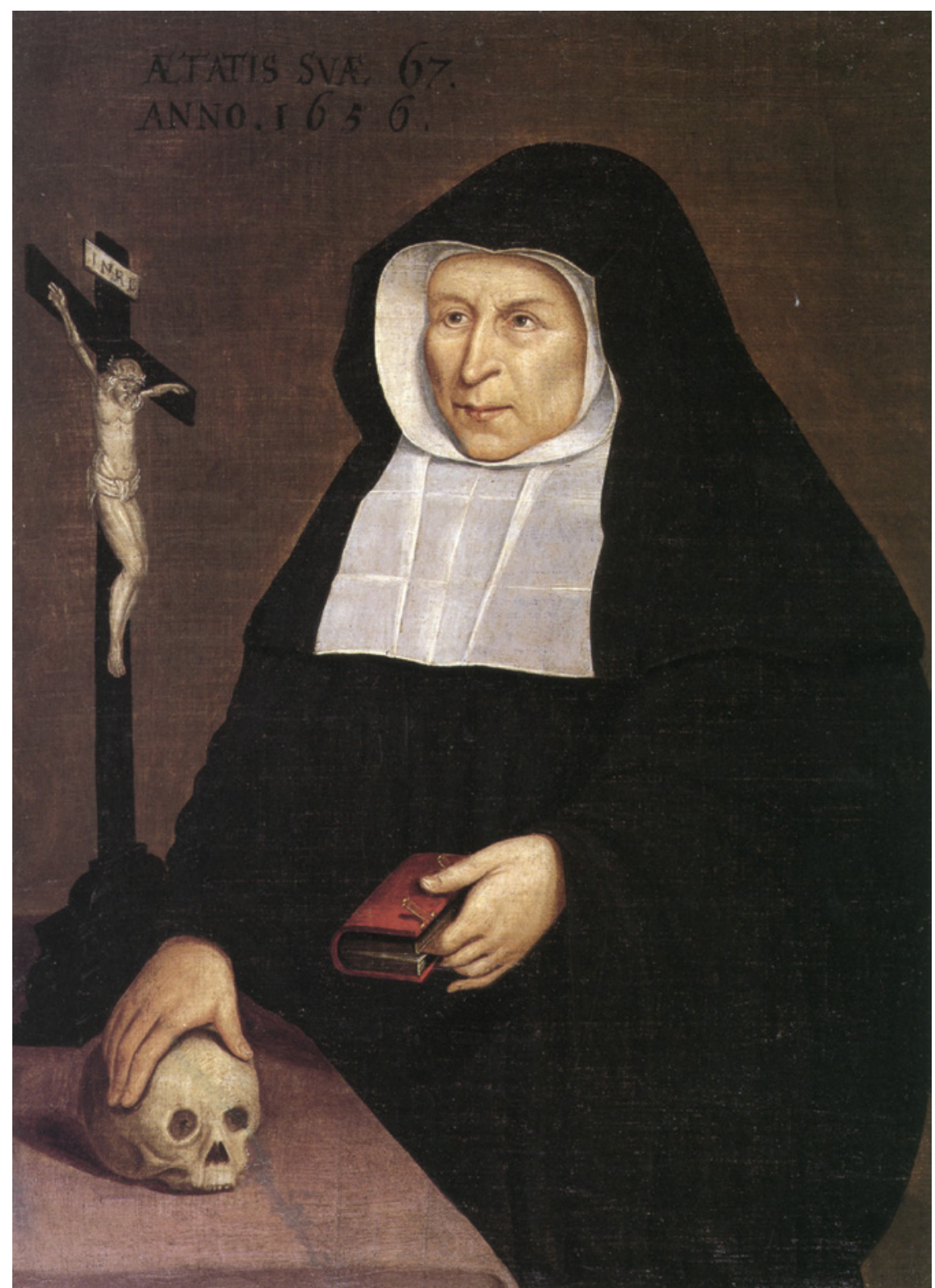

FIGURE 4.17 Anon., Portrait of a Benedictine Nun aged 67, 1656, until 2013 in the Abbey of Sint-Godelieve, Bruges

nose. The general effect is one of both literal and metaphoric seniority, the monastic equivalence of dignified grandmotherhood; pictures of senior nuns would very likely repay further study. Suffice it here to say that, within the walls 


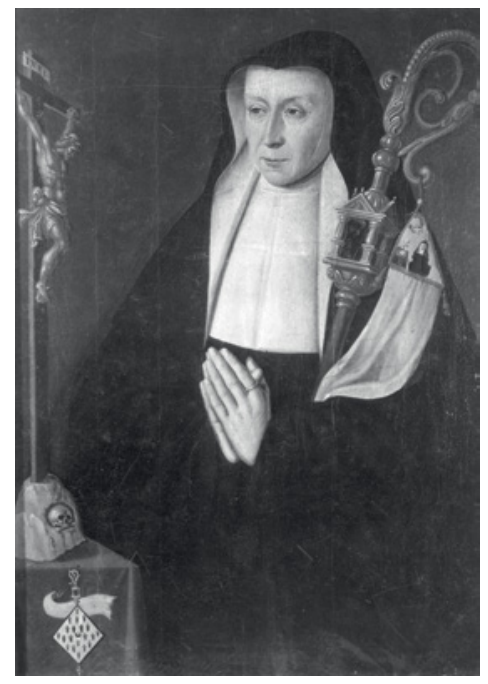

FIGURE 4.18

Anon., Florence de Werguignoeul, Abbess of Notre Dame de la Paix in Douai, 1627, until 2013 in the Abbey of Sint-Godelieve, Bruges

of Sint-Godelieve, such portrayals of conventual dignity would have been further underscored by other paintings of renowned Benedictine abbesses with similar faces, poses and attributes (see, for example, Fig. 4.18). Again, the effect would have been cumulative. In the early modern period, Sint-Godelieve came with a set of images clearly meant to foreground monastic lineage as well as a distinctly feminine type of authority rooted in physical and devotional seniority.

A slightly different example of this portrait type is of yet another unknown nun, this time an Augustinian from Mechlin (Fig. 4.19). ${ }^{63}$ It is an accomplished piece where the deliberately rough brushwork conveys the wonderfully distinct if forbidding features of a woman in late middle age, her mouth firmly set, her eyes almost invisible behind their droopy, lashless lids. One might even imagine that her eyes are in the process of rolling backwards into their lids, in a trancelike withdrawal from the present world. As in the two images from Sint-Godelieve, the overall impression is far removed from the flirtatiousness inherent in Penson's encounter with the pretty novice. This woman's portrait (or, perhaps, it is a tronie, though this does not fit with its conventual provenance) is far more suggestive of interiority, of contemplation. If images like this were hung in early modern convent parlours, they would have served as reminders of a type of feminine authority rooted simultaneously in seniority and in a withdrawal from the world into contemplation. At the same time, such portraits would have worked as foils simultaneously to foreground and hold in

63 Vandenbroeck, Hooglied, 137 and 236 (catalogue 87). 


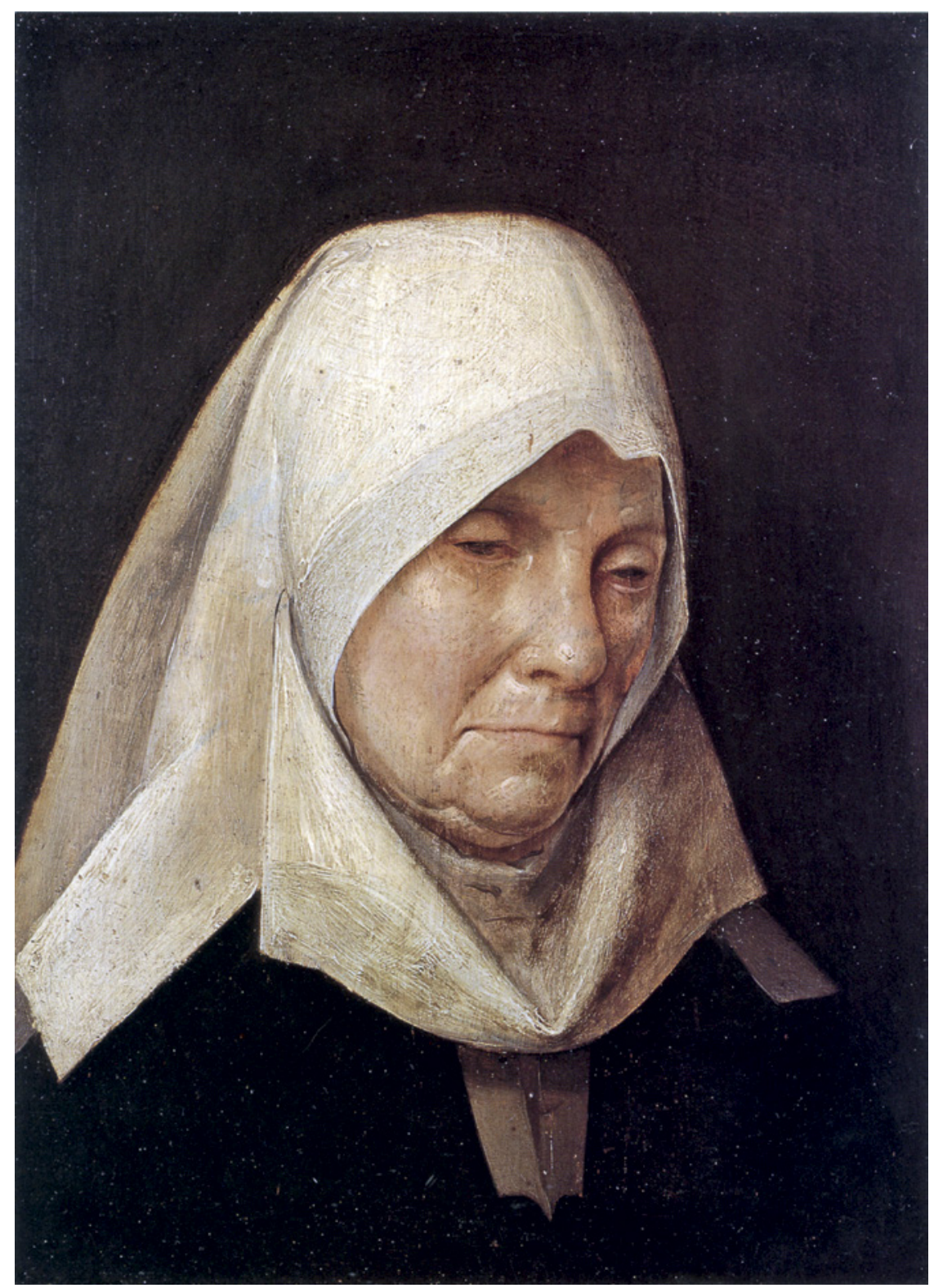

FIgUre 4.19 Anon., Portrait of an Augustinian sister, late sixteenth century (?), Diocesan Sisters, Overijse-Mechelen 
check some of the erotic charge that may have been sparked by younger, prettier nuns' faces. This is not a far-fetched suggestion given that, as Dürer's drawing of Metzgen shows (Fig. 4.8), in the early modern period there was a certain interest in juxtaposing the features of younger and older women.

In the Netherlands and beyond, early modern portraits of nuns come with an intractable sense of the generic. Nearly all of them conform to stereotype, fitting somewhere on a spectrum defined at one end by the austere yet womanly authority of the withdrawn senior nun and at the other by the sexual potency of the pretty young novice. Naturally there are many variations but most remain close to these twin themes of forbiddingly virtuous contemplation and desirable yet impeccable chastity. These two categories even seem to be at play in the few surviving early modern parodies of conventual portraiture, which represent either grotesque old age or naughtily unchaste youth. ${ }^{64}$

At the same time, it was patently important that nuns' portraits should evoke a certain if limited sense of individuality. Most of the images discussed in this essay have some features to mark them out as portraits, some distinguishing characteristics that prevent them from becoming wholly generic. That is even the case for the paintings from Sint-Catharinadal which cannot be defined as likenesses in any straightforward way. This, in turn, must have given evidential traction to a monastic ideal of youthful chastity - of what a sceptical yet fascinated lay visitor like Penson saw as a deliberate sacrifice of sexual currency in the cause of religion - that would eventually ripen into devout seniority. Nuns' portraits propagated the notion that such ideals could be and were made actual, that they corresponded with the lived experiences of real women.

This fits neatly with the two purposes of nuns' portraits identified above. Some were destined to hang in family homes, others were for convent parlours, both a type of space frequented by the laity, whether devout, sceptical or Protestant. Accordingly, such portraits were the nuns' faces to the world, both adverts for and guarantors of the virtues of monastic life, a particularly acute issue in confessional frontier zones like the Netherlands and England. Understood in this context, it is hardly surprising that early modern portraitists

64 For examples of this, see Viviana Farina, "Ribera's Satirical Portrait of a Nun," Master Drawings $5^{2}$ (2014): 471-480; and Melissa Percival, "Portraits of Mademoiselle de Charolais as a Franciscan Friar: Gender, Religion and Cross-Dressing," Art History 37 (2014): 890-911. 
of nuns worked with, around, and sometimes against a set of formulaic and thus easily recognisable pictorial ideals of feminine monastic piety.

On a broader level, these points may be linked to the many paradoxes and tensions inherent in the distinct gender roles occupied by early modern nuns. Although the sisters formally exchanged their natal for their monastic families, blood ties and familial status remained important both within and beyond their convents. Moreover, early modern nuns were meant to renounce sexuality to live exemplary corporate lives, whether in devout contemplation or in active charity, and yet they were never wholly outside the prevailing sexual economy nor, of course, could they shrug off all the other usual human foibles. That is one of the core lesson of early modern nuns' portraits: they show how taxing it was for these women and their portraitists to negotiate the many and sometime conflicting social expectations attendant on their monastic roles.

On this basis it could be argued that early modern nuns' portraits are so very generic because nuns, in themselves, had already taken on certain qualities of portraiture. Taking the veil and the habit entailed covering oneself with the identifying marks of the nun. It meant displaying palpably on and through one's body a certain submission to larger social and religious systems ranging across both space and time. In general, that is what early modern portraits do, by showing individuals performing a wide variety of (often distinctly gendered) social roles, from the sovereign ruler, the victorious warrior and the dedicated scholar to the court beauty, the devoted wife and the chaste nun. A nun was meant to fashion herself into the image of her role; her portrait both performed and exemplified that act of self-fashioning. 